\title{
Comparison of the HadGEM2 climate-chemistry model against in-situ and SCIAMACHY atmospheric methane data
}

\author{
G. D. Hayman et al.
}

Correspondence to: G. D. Hayman (garr@ceh.ac.uk) 


\section{Supplementary material}

\section{Emission Inventories}

\subsection{Wetlands and Wetland Emissions}

The methane emissions from wetlands used in this study were based on an offline global monthly run of the JULES land-surface model for $0.5^{\circ} \times 0.5^{\circ}$ terrestrial grid squares for the period from January 1980 to December 2010, using CRU-NCEP driving meteorological data (Viovy and Ciais, 2009). JULES (Joint UK land earth simulator) is a physically-based model that contains description of water, energy and carbon balances and temperature, moisture and carbon stores (Best et al., 2011; Clark et al., 2011). JULES (v3.1) uses a methane wetland emission parameterization, developed and tested by Gedney et al. (2004) for use at large spatial scales. The wetland parameterization is coupled to the large-scale hydrology scheme of Gedney and Cox (2003), which predicts the distribution of sub-grid scale water table depth and wetland fraction from the overall soil moisture content and the sub-grid scale topography.

Fig. 1 compares maps of the maximum inundation fraction in each grid square for monthly data from January 1993 to December 2007, as derived from (a) the offline JULES run described above and (b) regridding the global inundation extent multi-sensor (GIEMS) product of Prigent et al. (2012). While JULES captures the major wetland areas, it is clear that JULES underestimates the magnitude. The JULES wetlands areas are more extensive spatially, especially over the Amazon, and smoother. Collins et al. (2011) indicated that the greater spatial extent of wetlands over the Amazon was linked to the poor data on the underlying rock topography in this region incorporated into the ancillary topographic index dataset. Changes are being made to the JULES wetland parameterisation and these are currently being evaluated (Gedney, 2014).

In addition to the standard output (denoted JULES), a second wetland emission estimate was derived from this JULES offline run by replacing the modelled wetland fraction with the wetland fraction from the regridded GIEMS product (denoted JULES-GIEMS). Emission fluxes for the latter could only be derived for the period from January 1993 to December 2007. Fig. 2 shows maps of the annual emissions of methane from wetlands in 2000 derived from the above. The two JULES inventories were separately scaled to give a mean annual emission of $181 \mathrm{Tg}$ $\mathrm{CH}_{4}$ per annum for the years 1999-2007, the period of the HadGEM2 model runs.

In the JULES wetland emission dataset, most of the emissions occur from the tropics, especially from the Amazon. The use of the EO data is to slightly shift the emissions away from the tropics towards the boreal zone. This is more clearly seen in the zonal plots of Fig. 3, which compare the latitudinal distributions of the methane emissions derived from (a) the JULES and the JULES-GIEMS runs for the year 2000; (b) the inventory of Fung et al. (1991) for wetlands (=wetlands+bogs+swamps+tundra) and for wetlands and rice paddy fields. The JULES methane inventories have more emissions in the tropics compared to the wetlands dataset of Fung et al. (1991).

The EO wetland inundation product does not discriminate between natural wetlands and managed water areas such as rice paddy fields. A correction was made for the rice paddy fields in the EO wetland product using information on the area of cultivation of rice, from both irrigated and rain-fed cultivation (Portmann et al., 2010). The left-hand panel (a) has no correction to the EO wetland fraction. The right-hand panel (b) shows the effect of correcting the EO wetland inundation product for the area of rice paddy fields. The effect of correcting for the methane emissions from rice paddy fields is most noticeable in the latitude band between $10^{\circ}$ and $30^{\circ} \mathrm{N}$. The corrected wetland emission dataset was used in the HadGEM model run and an additional term of $40 \mathrm{Tg} \mathrm{CH}_{4}$ per annum was added to the non-wetland methane sources to represent emissions from rice paddy fields. 

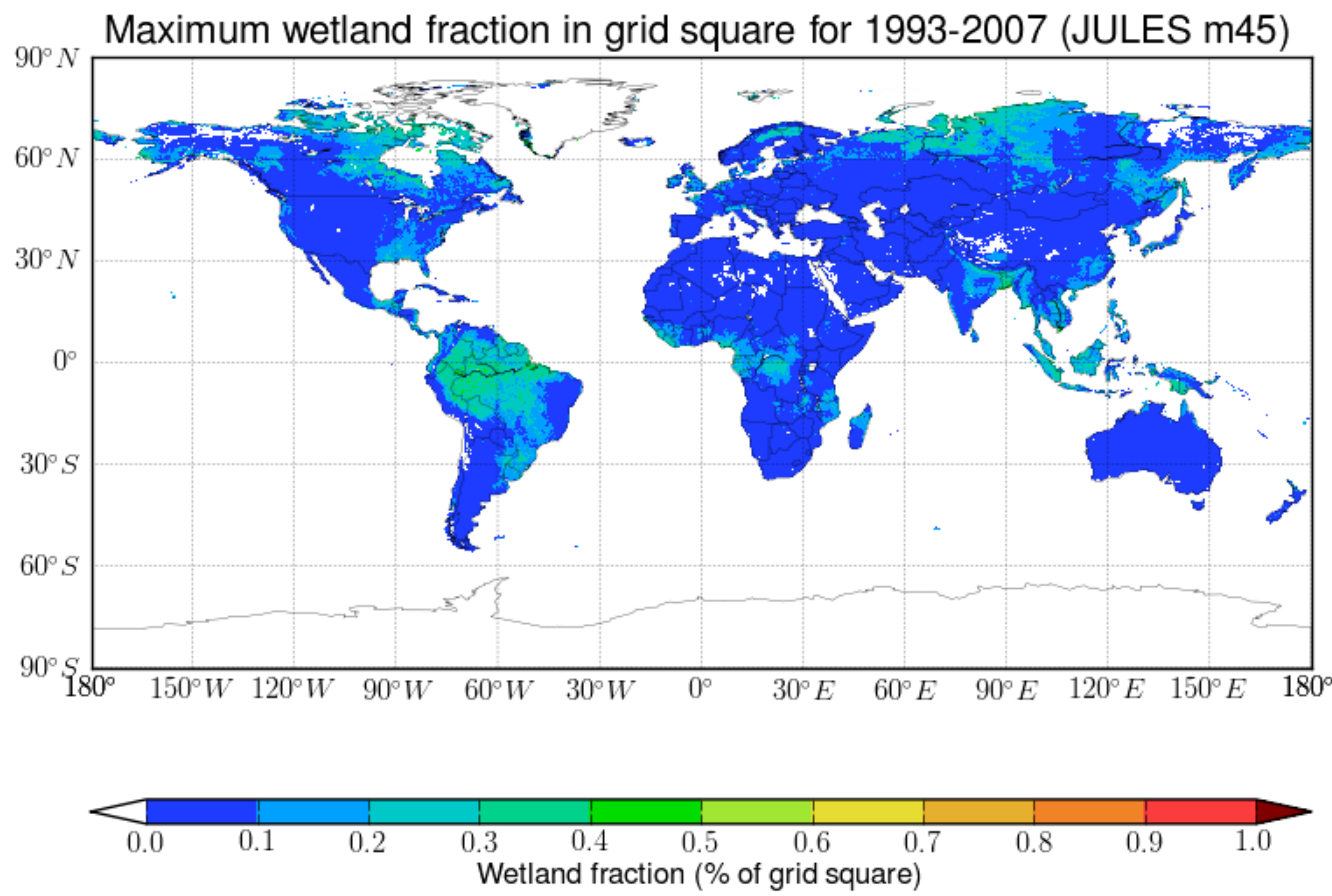

(b)

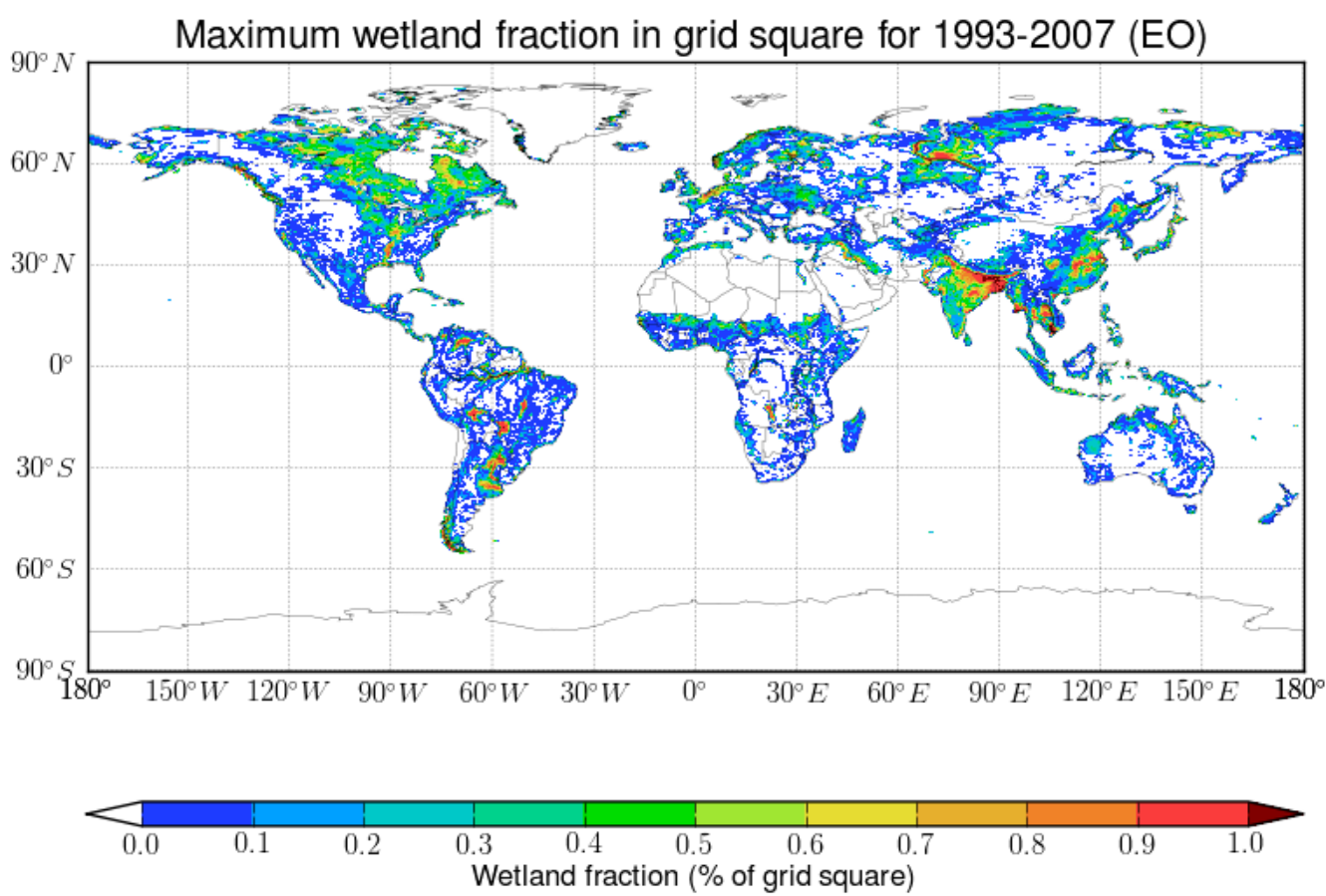

Figure 1: Maps of the maximum inundation fraction in each grid square for monthly data from January 1993 to December 2007, as derived from (a) an offline JULES run using the standard configuration and (b) the Earth Observation Global Inundation Extent Multi-Sensor (GIEMS) product of Prigent et al. (2012). 
(a)
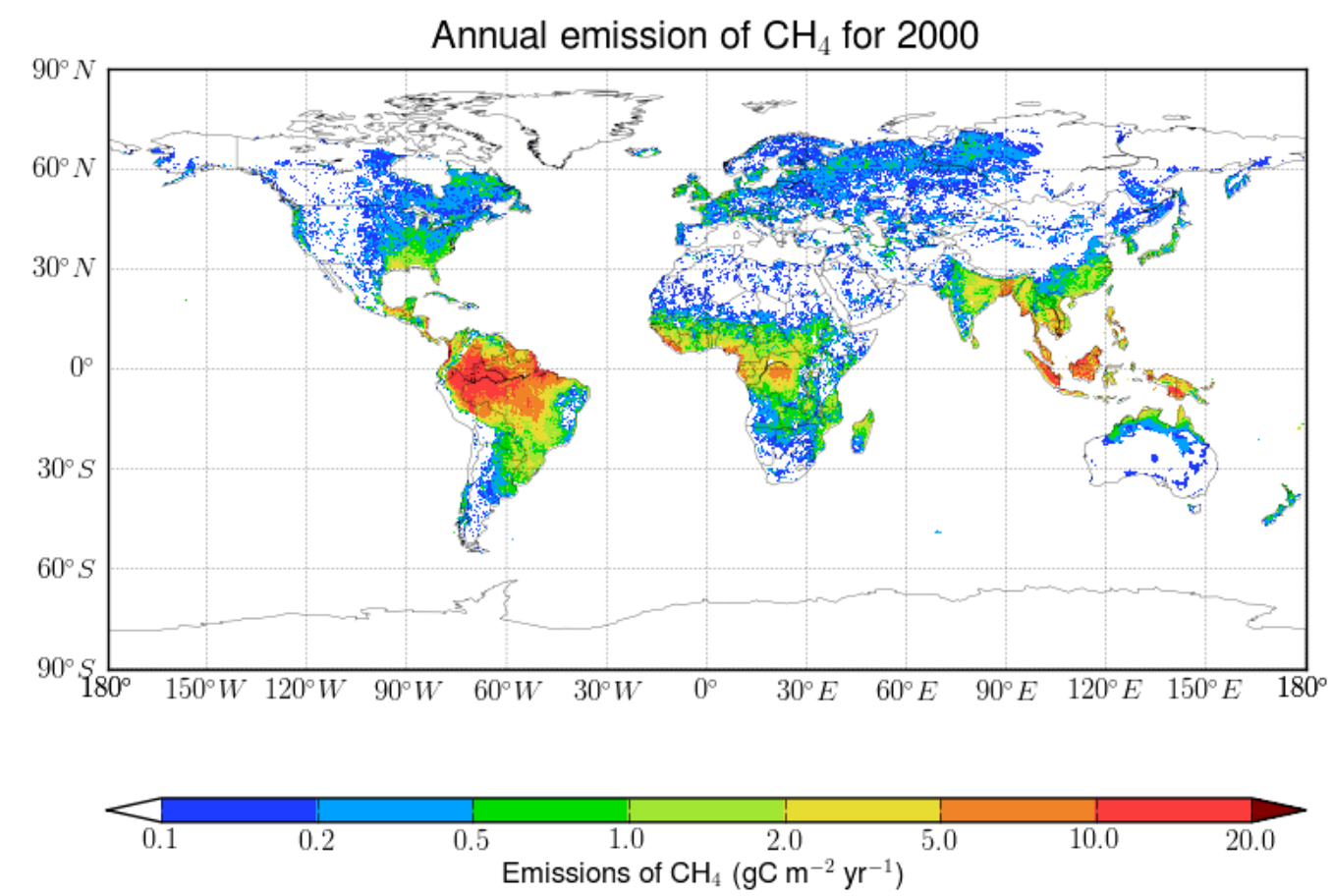

(b)

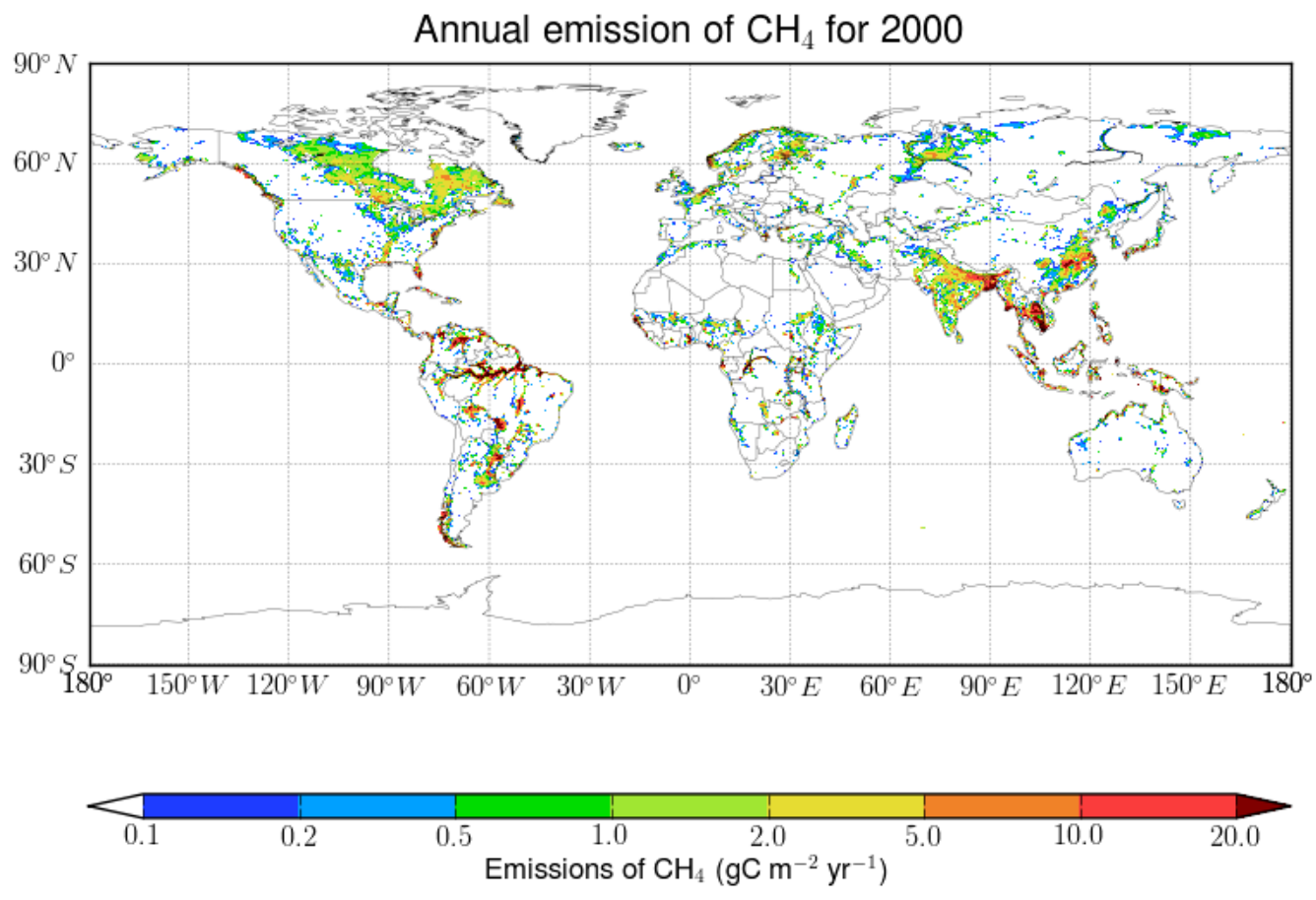

Figure 2: Maps of the annual emissions of methane from wetlands in 2000 from (a) an offline JULES run using the standard configuration and the modelled wetland fraction and (b) the same offline JULES run in which the modelled wetland fraction is replaced with the EO-derived wetland fraction. 
(a)

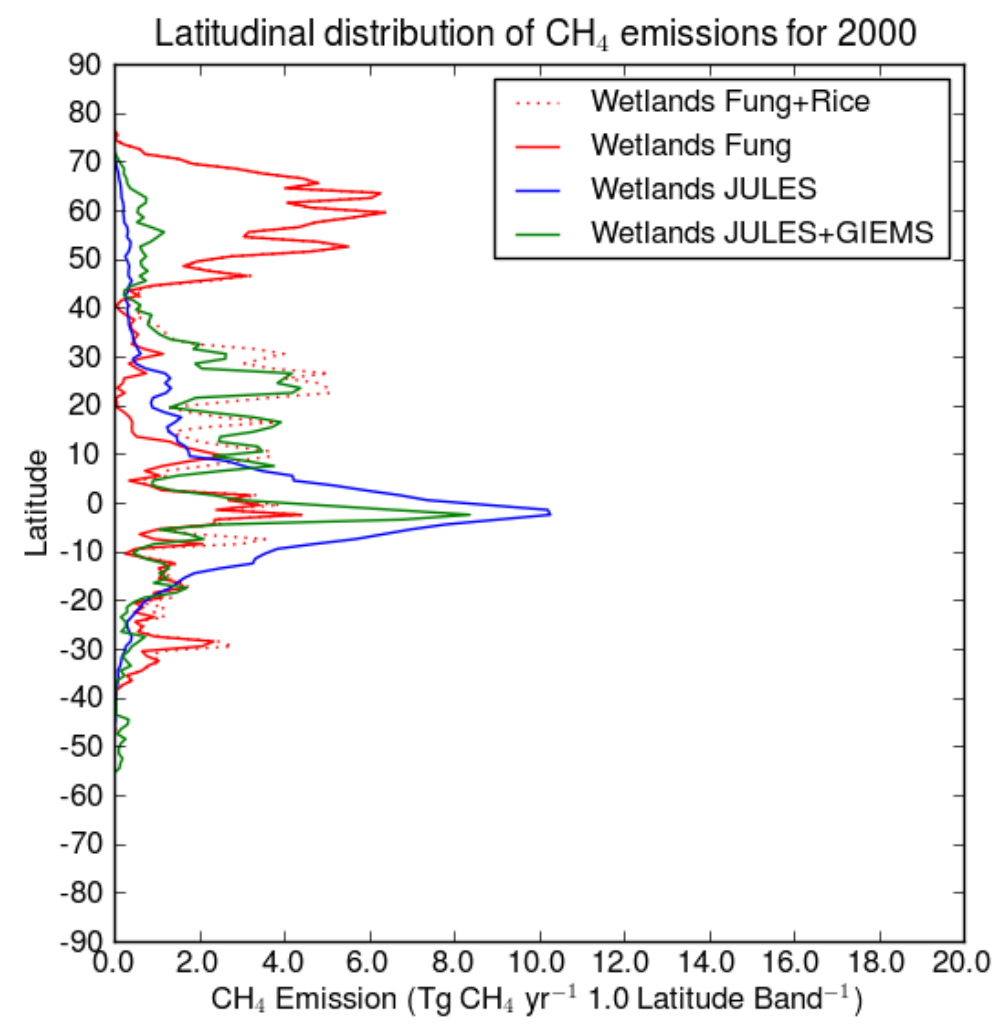

(b)

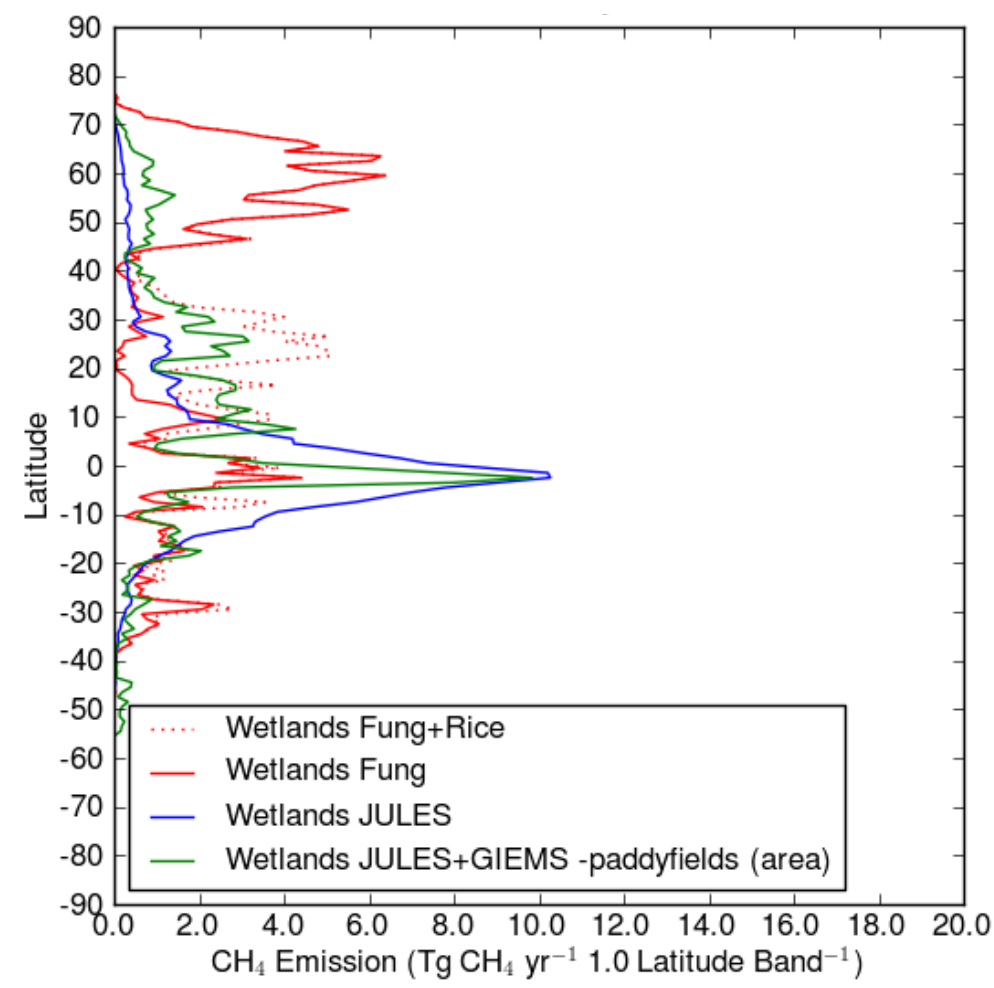

Figure 3: The latitudinal distributions of (i) the wetland methane emissions from JULES for the year 2000, denoted JULES (red lines); (ii) the wetland methane emissions from JULES for the year 2000 with the modeled wetland fraction replaced with an EO-derived wetland fraction, denoted JULES EO (blue lines); (iii) the methane emissions derived from the inventory of Fung et al. (1991) for wetlands (see text) [solid black lines]; (iv) the methane emissions derived from the inventory of Fung et al. (1991) for wetlands and for rice paddy fields [dotted black lines]. Panel (a) has no correction to the EO wetland fraction. Panel (b) shows the effect of correcting the EO wetland inundation product for the area of rice paddy fields. 
Tab. 1 summarises the latitudinal breakdown of the JULES-based global annual methane emissions from wetlands used in this study. The JULES methane inventories have more emissions in the tropics compared to the wetlands dataset of Fung et al. (1991).

Table 1: Latitudinal breakdown of different global annual methane emissions from wetlands for the year 2000 .

\begin{tabular}{l|c|c|c|c|c}
\hline Emission Dataset & $\begin{array}{c}\text { Extratropical } \\
\mathrm{SH} \\
\left(90^{\circ} \mathrm{S}-30^{\circ} \mathrm{S}\right)\end{array}$ & $\begin{array}{c}\text { Tropical } \\
\left(30^{\circ} \mathrm{S}-30^{\circ} \mathrm{N}\right)\end{array}$ & $\begin{array}{c}\text { Extratropical } \\
\mathrm{NH} \\
\left(30^{\circ} \mathrm{N}-50^{\circ} \mathrm{N}\right)\end{array}$ & Boreal/Arctic & Global \\
\hline $\begin{array}{l}F U N G \text { Wetlands and Rice } \\
\text { paddy fields }\end{array}$ & 5.7 & 133.2 & 30.2 & 90.8 & 259.9 \\
$\begin{array}{l}F U N G \text { Wetlands } \\
\text { JULES Wetlands }\end{array}$ & 5.0 & 67.1 & 18.1 & 90.8 & 181.0 \\
$\begin{array}{l}J U L E S-G I E M S \text { Wetlands: } \\
\text { no correction }\end{array}$ & 4.5 & 167.4 & 7.7 & 4.5 & 181.1 \\
$\begin{array}{l}\text { JULES-GIEMS Wetlands: } \\
\text { correction }\end{array}$ & 4.9 & 132.1 & 18.3 & 12.2 & 166.7 \\
\hline
\end{tabular}

\subsection{Global Emissions}

Year- and month-specific emission datasets were generated for the period from 1997 to 2009 for (a) non-wetland methane sources and (b) the other emitted species in the UKCA standard troposheric chemistry scheme $\left(\mathrm{CO}, \mathrm{NO}_{x}, \mathrm{HCHO}, \mathrm{CH}_{4}, \mathrm{C}_{2} \mathrm{H}_{6}, \mathrm{C}_{3} \mathrm{H}_{8}, \mathrm{CH}_{3} \mathrm{CHO}, \mathrm{CH}_{3} \mathrm{CHOCH}_{3}\right.$ O'Connor et al., 2013). The approach adopted varied depending on the source sector:

- Anthropogenic: The emissions from anthropogenic sources were based on the decadalaveraged emission inventories compiled by Lamarque et al. (2010) for the Coupled Carbon Cycle Climate Model Intercomparison Project (C4MIP) undertaken for the fifth IPCC assessment report (AR5). The decadal-averaged inventories were used to derive yearspecific emission datasets by scaling the emission totals for the different years and source sectors using sector and species-specific scaling factors based on the annual trends given in various EDGAR time series: (a) version 4.2 for all species (except NMVOCs) and version 4.1 for NMVOCs; (b) v3.2. This approach was also applied to the emissions from aviation (only for oxides of nitrogen) and international shipping.

- Biomass burning: Year-specific emission inventories are available from the Global Fire Emissions Database (GFED, v3.1) for the years 1997 to 2009 (van der Werf et al., 2010), on a monthly timestep. The methane emissions were scaled to give the same decadal mean, $25 \mathrm{Tg} \mathrm{CH}_{4}$ per annum averaged over 1997 to 2005, as used in the study of O'Connor et al. (2013) to evaluate the standard troposheric chemistry scheme.

- Other: Sources such as termites and hydrates for methane and oceanic emissions of $\mathrm{CH}_{4}$ and other volatile organic compounds were taken from various sources, as described in O'Connor et al. (2013). These datasets contain a single annual cycle, which was assumed to apply for all years.

\subsubsection{Methane}

Tab. 2 provides a breakdown by source sector of the global annual emissions of methane used in the different HadGEM2 model for the year 2000. Tab. 3 gives the annual global emissions for the different runs from 1997 to 2008. 
Table 2: Comparison of the global annual emissions of methane for 2000 (in $\mathrm{Tg} \mathrm{CH}_{4}$ per annum) and their breakdown by major source sector for the HadGEM2 runs using the following wetland emission inventories, FUNG, JULES and JULES-GIEMS.

\begin{tabular}{l|c|c|c}
\hline Emission Sector & $F U N G$ & JULES & JULES-GIEMS \\
\hline anthropogenic & 299.2 & 299.2 & 299.2 \\
shipping & 0.4 & 0.4 & 0.4 \\
wetlands & 181.1 & 181.2 & 165.4 \\
biomass burning & 15.6 & 15.6 & 15.6 \\
termites & 20.0 & 20.0 & 20.0 \\
hydrates \& oceanic emissions & 25.0 & 25.0 & 25.0 \\
\hline TOTAL & 541.3 & 541.4 & 525.6 \\
\hline
\end{tabular}

Note: The anthropogenic term includes $40 \mathrm{Tg} \mathrm{CH}_{4}$ per annum of emissions from rice paddy fields.

Table 3: Time series of the global annual emissions of methane from 1997 to 2008 (in Tg per annum) used in the ALANIS methane base case and scenario runs and the Hadley Centres decadal-averaged inventories.

\begin{tabular}{l|c|c|c}
\hline Year & $F U N G$ & JULES & JULES-GIEMS \\
\hline 1997 & 578.4 & 572.6 & 579.7 \\
1998 & 556.0 & 554.1 & 569.4 \\
1999 & 543.8 & 542.1 & 543.2 \\
2000 & 541.3 & 541.4 & 525.6 \\
2001 & 541.1 & 538.2 & 530.3 \\
2002 & 551.4 & 550.8 & 562.4 \\
2003 & 548.0 & 547.4 & 550.1 \\
2004 & 546.9 & 547.6 & 540.7 \\
2005 & 549.1 & 549.8 & 548.5 \\
2006 & 554.2 & 556.8 & 565.0 \\
2007 & 547.1 & 548.6 & 558.2 \\
2008 & 542.4 & 545.7 & 545.1 \\
2009 & 542.2 & 545.9 & 548.9 \\
\hline
\end{tabular}

Fig. 4-6 show plots of (a) the time series of the annual methane emissions from from wetlands

TRANSCOM regions for three of the HadGEM2 runs (FUNG, JULES, JULES-GIEMS). 


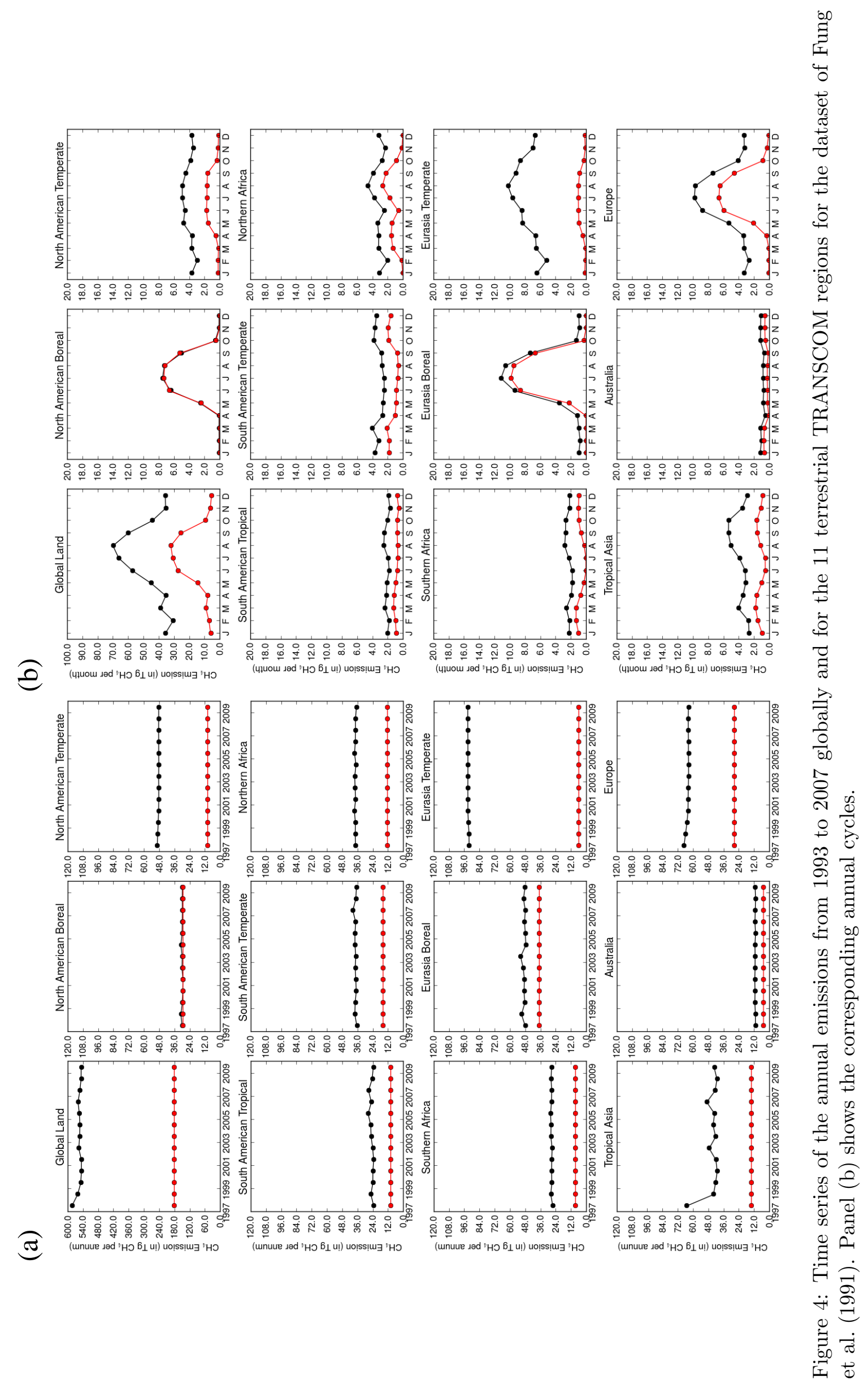




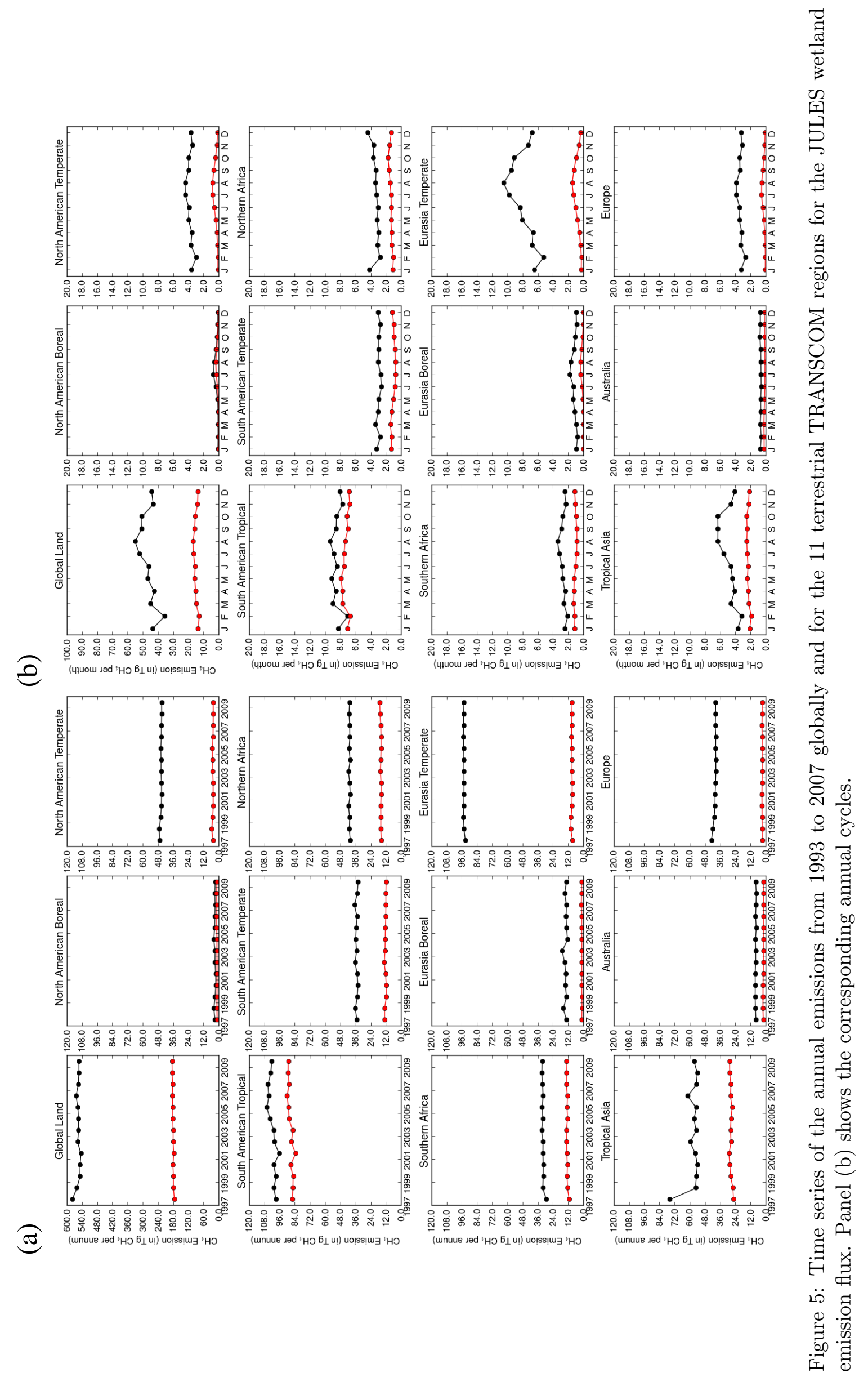




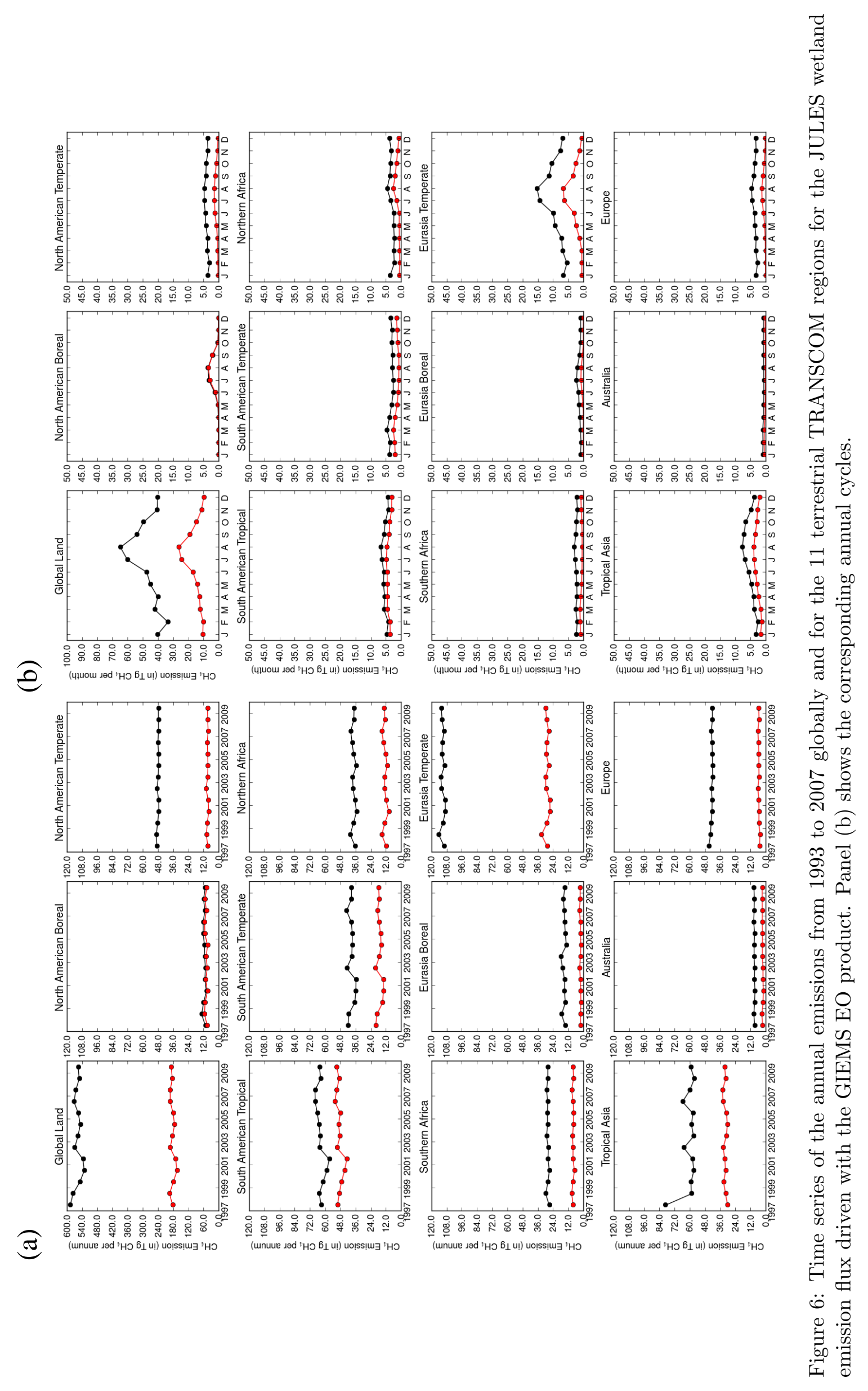




\subsubsection{Other emitted species}

Table 4: Breakdown of the global annual emissions by sector and year of those non-methane trace gases that have emissions in the UKCA Standard Troposphere chemistry scheme.

(a) Carbon Monoxide (in $\mathrm{Tg} \mathrm{CO} \mathrm{yr}{ }^{-1}$ )

\begin{tabular}{l|c|c|c|c|c}
\hline Year & Anthropogenic & Biomass Burning & Shipping/Aviation & Other & Total \\
\hline 1997 & 607.5 & 736.4 & 1.1 & 520.0 & 1864.9 \\
1998 & 607.5 & 594.5 & 1.1 & 520.0 & 1723.1 \\
1999 & 607.5 & 378.4 & 1.2 & 520.0 & 1507.0 \\
2000 & 607.5 & 328.7 & 1.2 & 520.0 & 1457.3 \\
2001 & 607.5 & 311.5 & 1.1 & 520.0 & 1440.1 \\
2002 & 607.5 & 463.9 & 1.2 & 520.0 & 1592.6 \\
2003 & 607.5 & 449.4 & 1.2 & 520.0 & 1578.1 \\
2004 & 607.5 & 411.7 & 1.3 & 520.0 & 1540.5 \\
2005 & 607.5 & 442.2 & 1.3 & 520.0 & 1571.0 \\
2006 & 607.5 & 476.8 & 1.4 & 520.0 & 1605.7 \\
2007 & 607.5 & 417.9 & 1.5 & 520.0 & 1546.9 \\
\hline
\end{tabular}

(b) Oxides of Nitrogen (in $\mathrm{Tg} \mathrm{NO}_{\mathrm{x}}$ as $\mathrm{N} \mathrm{yr}^{-1}$ )

\begin{tabular}{l|c|c|c|c|c}
\hline Year & Anthropogenic & Biomass Burning & Shipping/Aviation & Other & Total \\
\hline 1997 & 26.1 & 6.4 & 6.0 & 5.9 & 44.4 \\
1998 & 26.6 & 7.1 & 6.0 & 5.9 & 45.6 \\
1999 & 27.1 & 4.7 & 6.4 & 5.9 & 44.1 \\
2000 & 27.7 & 4.2 & 6.6 & 5.9 & 44.3 \\
2001 & 28.2 & 3.9 & 6.3 & 5.9 & 44.2 \\
2002 & 28.7 & 5.3 & 6.5 & 5.9 & 46.3 \\
2003 & 29.4 & 5.6 & 6.6 & 5.9 & 47.4 \\
2004 & 29.9 & 4.9 & 7.3 & 5.9 & 48.0 \\
2005 & 30.4 & 5.2 & 7.3 & 5.9 & 48.8 \\
2006 & 31.0 & 5.1 & 7.8 & 5.9 & 49.7 \\
2007 & 31.6 & 5.0 & 8.2 & 5.9 & 50.7 \\
\hline
\end{tabular}

(c) Formaldehyde (in $\mathrm{Tg} \mathrm{HCHO} \mathrm{yr}^{-1}$ )

\begin{tabular}{l|c|c|c|c|c}
\hline Year & Anthropogenic & Biomass Burning & Shipping/Aviation & Other & Total \\
\hline 1997 & 3.2 & 8.2 & - & - & - \\
1998 & 3.2 & 7.8 & - & - & 11.3 \\
1999 & 3.2 & 5.1 & - & - & 8.2 \\
2000 & 3.2 & 4.4 & - & - & 7.6 \\
2001 & 3.2 & 4.1 & - & - & 7.3 \\
2002 & 3.2 & 5.8 & - & - & 9.0 \\
2003 & 3.2 & 5.9 & - & - & 9.1 \\
2004 & 3.3 & 5.4 & - & - & 8.7 \\
2005 & 3.3 & 5.9 & - & - & 9.3 \\
2006 & 3.4 & 5.9 & - & - & 9.3 \\
2007 & 3.4 & 5.8 & - & & 9.2 \\
\hline
\end{tabular}

(d) Ethane (in $\mathrm{Tg} \mathrm{C}_{2} \mathrm{H}_{6} \mathrm{yr}^{-1}$ )

\begin{tabular}{l|c|c|c|c|c}
\hline Year & Anthropogenic & Biomass Burning & Shipping/Aviation & Other & Total \\
\hline 1997 & 13.9 & 16.3 & 0.4 & - & 30.6 \\
1998 & 13.9 & 15.6 & 0.4 & - & 29.9 \\
1999 & 13.9 & 10.1 & 0.4 & - & 24.4 \\
2000 & 13.9 & 8.8 & 0.4 & - & 23.1 \\
2001 & 14.0 & 8.2 & 0.4 & - & 22.6 \\
2002 & 14.0 & 11.6 & 0.4 & - & 26.0 \\
2003 & 14.2 & 11.8 & 0.4 & - & 26.4 \\
2004 & 14.5 & 10.8 & 0.5 & - & 25.8 \\
2005 & 14.6 & 11.8 & 0.5 & - & 26.9 \\
2006 & 14.9 & 11.8 & 0.5 & - & 27.2 \\
2007 & 15.1 & 11.5 & 0.6 & & 27.2 \\
\hline
\end{tabular}


Table 4 (continued): Breakdown of the global annual emissions by sector and year of those non-methane trace gases that have emissions in the UKCA Standard Troposphere chemistry scheme.

(e) Propane (in $\mathrm{Tg} \mathrm{C}_{3} \mathrm{H}_{8} \mathrm{yr}^{-1}$ )

\begin{tabular}{l|c|c|c|c|c}
\hline Year & Anthropogenic & Biomass Burning & Shipping/Aviation & Other & Total \\
\hline 1997 & 6.6 & 8.5 & 0.7 & - & 15.7 \\
1998 & 6.6 & 8.2 & 0.7 & - & 15.4 \\
1999 & 6.6 & 5.3 & 0.7 & - & 12.5 \\
2000 & 6.6 & 4.6 & 0.7 & - & 11.9 \\
2001 & 6.6 & 4.3 & 0.7 & - & 11.6 \\
2002 & 6.6 & 6.0 & 0.7 & - & 13.3 \\
2003 & 6.7 & 6.1 & 0.7 & - & 13.6 \\
2004 & 6.9 & 5.7 & 0.8 & - & 13.3 \\
2005 & 6.9 & 6.2 & 0.8 & - & 13.9 \\
2006 & 7.0 & 6.1 & 0.9 & - & 14.0 \\
2007 & 7.1 & 6.0 & 1.0 & - & 14.1 \\
\hline
\end{tabular}

(f) Acetaldehyde (in $\mathrm{Tg} \mathrm{CH}_{3} \mathrm{CHO} \mathrm{yr}^{-1}$ )

\begin{tabular}{|c|c|c|c|c|c|}
\hline Year & Anthropogenic & Biomass Burning & Shipping/Aviation & Other & Total \\
\hline 1997 & - & 12.4 & - & - & 12.4 \\
\hline 1998 & - & 11.9 & - & - & 11.9 \\
\hline 1999 & - & 7.7 & - & - & 7.7 \\
\hline 2000 & - & 6.6 & - & - & 6.6 \\
\hline 2001 & - & 6.2 & - & - & 6.2 \\
\hline 2002 & - & 8.8 & - & - & 8.8 \\
\hline 2003 & - & 8.9 & - & - & 8.9 \\
\hline 2004 & - & 8.2 & - & - & 8.2 \\
\hline 2005 & - & 9.0 & - & - & 9.0 \\
\hline 2006 & - & 8.9 & - & - & 8.9 \\
\hline 2007 & - & 8.7 & - & - & 8.7 \\
\hline
\end{tabular}

(g) Acetone (in $\mathrm{Tg} \mathrm{CH}_{3} \mathrm{COCH}_{3} \mathrm{yr}^{-1}$ )

\begin{tabular}{l|c|c|c|c|c}
\hline Year & Anthropogenic & Biomass Burning & Shipping/Aviation & Other & Total \\
\hline 1997 & 0.7 & 7.0 & - & 40.0 & 47.6 \\
1998 & 0.7 & 6.7 & - & 40.0 & 47.3 \\
1999 & 0.7 & 4.3 & - & 40.0 & 45.0 \\
2000 & 0.7 & 3.7 & - & 40.0 & 44.4 \\
2001 & 0.7 & 3.5 & - & 40.0 & 44.2 \\
2002 & 0.7 & 5.9 & - & 40.0 & 45.6 \\
2003 & 0.7 & 4.0 & - & 40.0 & 45.7 \\
2004 & 0.7 & 5.1 & - & 40.0 & 45.3 \\
2005 & 0.7 & 5.0 & - & 40.0 & 45.8 \\
2006 & 0.7 & 4.9 & - & 40.0 & 45.7 \\
2007 & 0.7 & \multicolumn{2}{c}{} \\
\hline
\end{tabular}

Notes to Table 4:

1. For $\mathrm{CO}$, the 'Other' category includes emission terms of (a) $475 \mathrm{Tg} \mathrm{CO} \mathrm{yr}^{-1}$ to account for the impact of isoprene emissions from vegetation on atmospheric composition, and (b) $45 \mathrm{Tg} \mathrm{yr}^{-1}$ from oceanic sources.

2. For $\mathrm{NO}_{x}$, the 'Other' category includes $5.9 \mathrm{Tg} \mathrm{NO}_{x} \mathrm{yr}^{-1}$ from soils. The emissions of $\mathrm{NO}_{x}$ from lightning are calculated interactively (O'Connor et al., 2013).

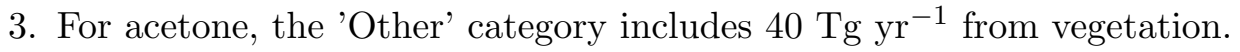




\subsection{Comparison with Estimates from Inverse Modelling}

95 and are compared, as difference maps, with the emissions derived from the inverse modelling study of Bousquet et al. (2011) in Figs. 7 to 12:

- Fig. 7: Maps of the global monthly methane emissions from wetlands in 2000 for the JULES wetland emission flux.

- Fig. 8: Maps of the difference in the global monthly methane emissions from wetlands in 2000 from the JULES run and from the inverse modelling study of Bousquet et al. (2011) using the Fung et al. (1991) dataset as the wetland emission prior.

- Fig. 9: Maps of the difference in the global monthly methane emissions from wetlands in 2000 from the JULES run and from the inverse modelling study of Bousquet et al. (2011) using the Kaplan dataset as the wetland emission prior.

- Fig. 10: Maps of the global monthly methane emissions from wetlands in 2000 for the JULES-GIEMS wetland emission flux with the modelled wetland fraction replaced with that derived from the GIEMS EO product.

- Fig. 11: Maps of the difference in the global monthly methane emissions from wetlands in 2000 from the JULES-GIEMS run and from the inverse modelling study of Bousquet et al. (2011) using the Fung et al. (1991) dataset as the wetland emission prior.

- Fig. 12: Maps of the difference in the global monthly methane emissions from wetlands in 2000 from the JULES run and from the inverse modelling study of Bousquet et al. (2011) using the Kaplan dataset as the wetland emission prior. 

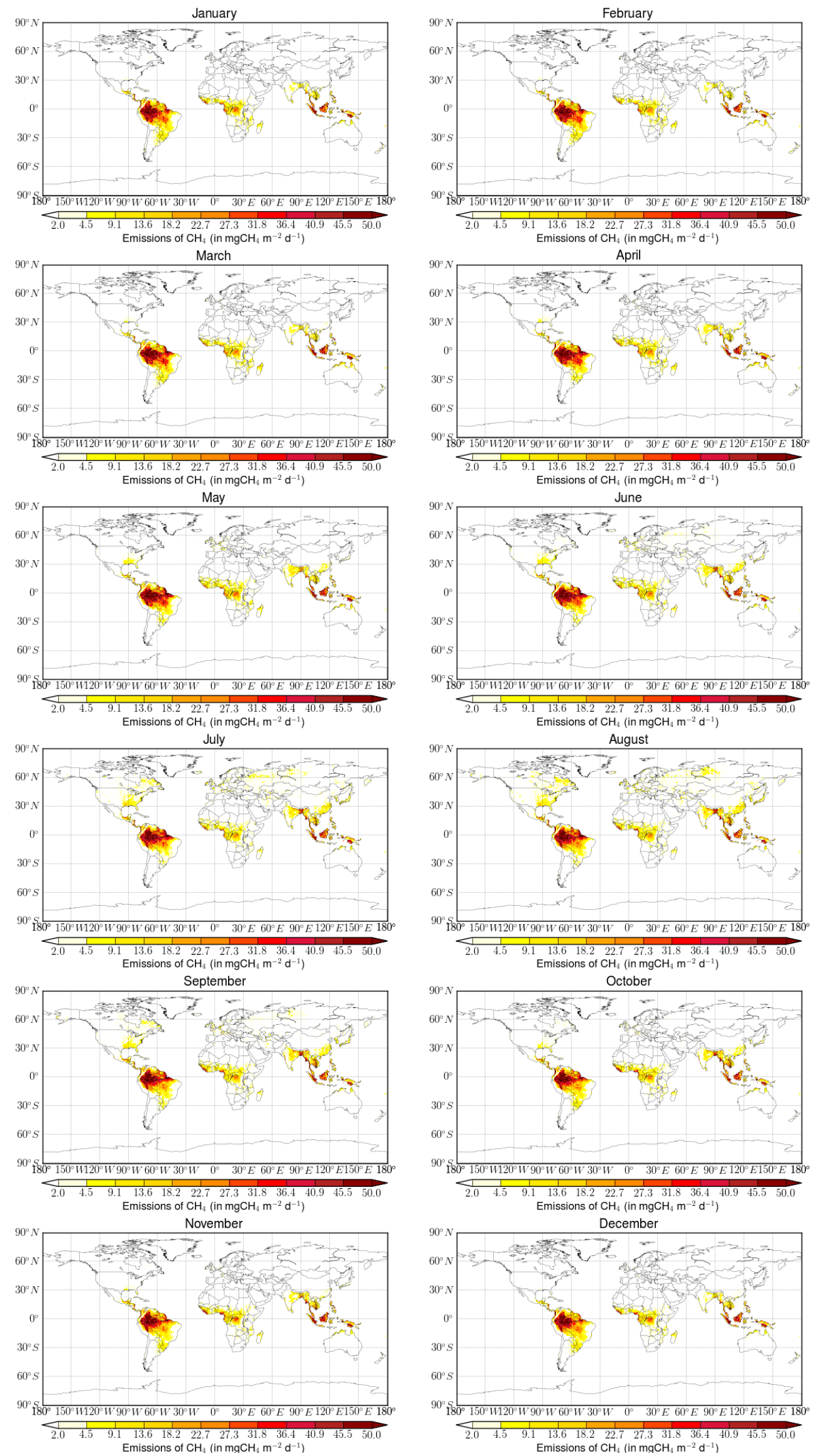

Figure 7: Maps of the global monthly wetland methane emissions for 2000 for the JULES wetland emission flux. 

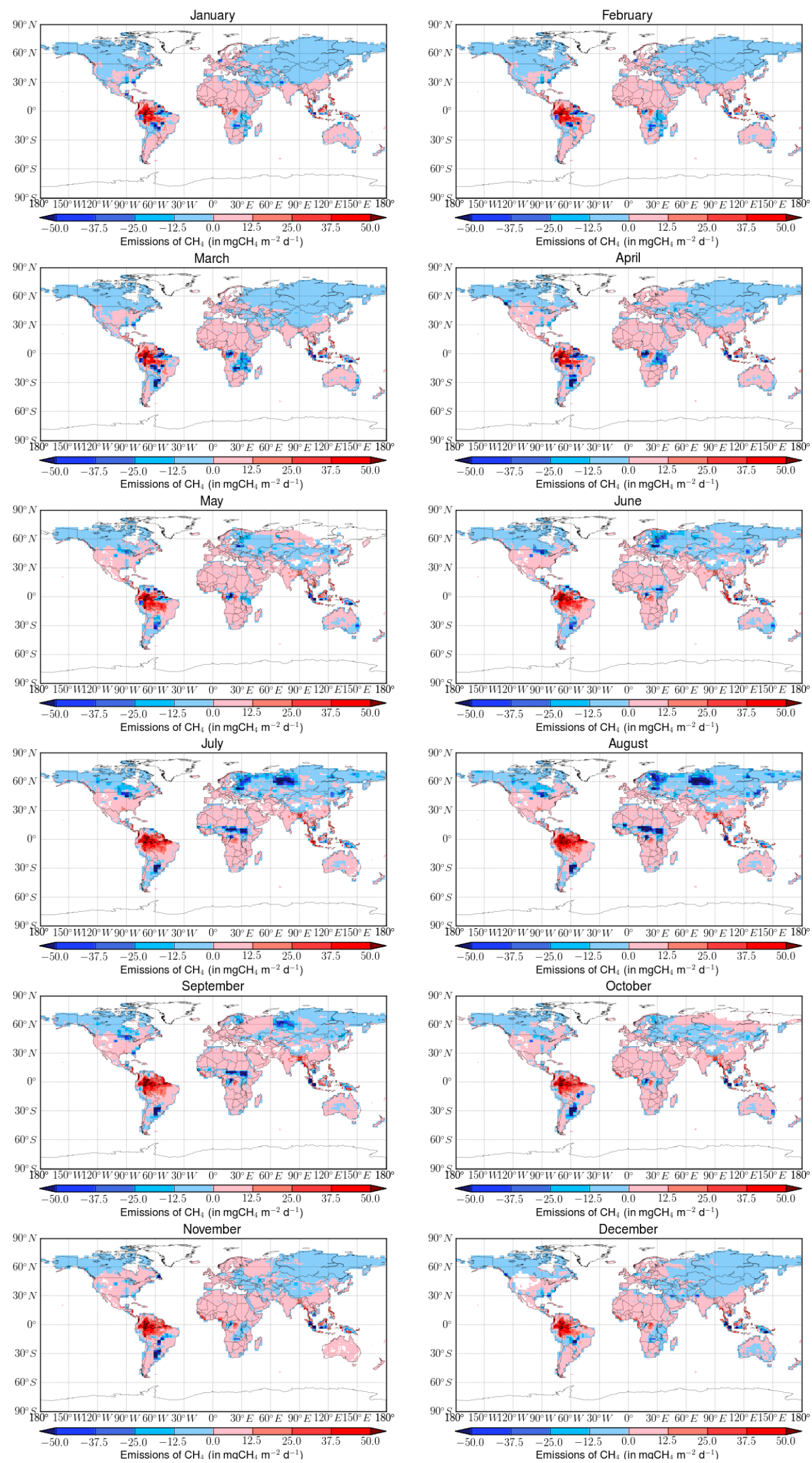

Figure 8: Maps of the differences in the global monthly wetland methane emissions for 2000 between the JULES wetland emission flux and the inverse modelling study of Bousquet et al. (2011) using the Fung et al. (1991) dataset as the wetland emission prior. 

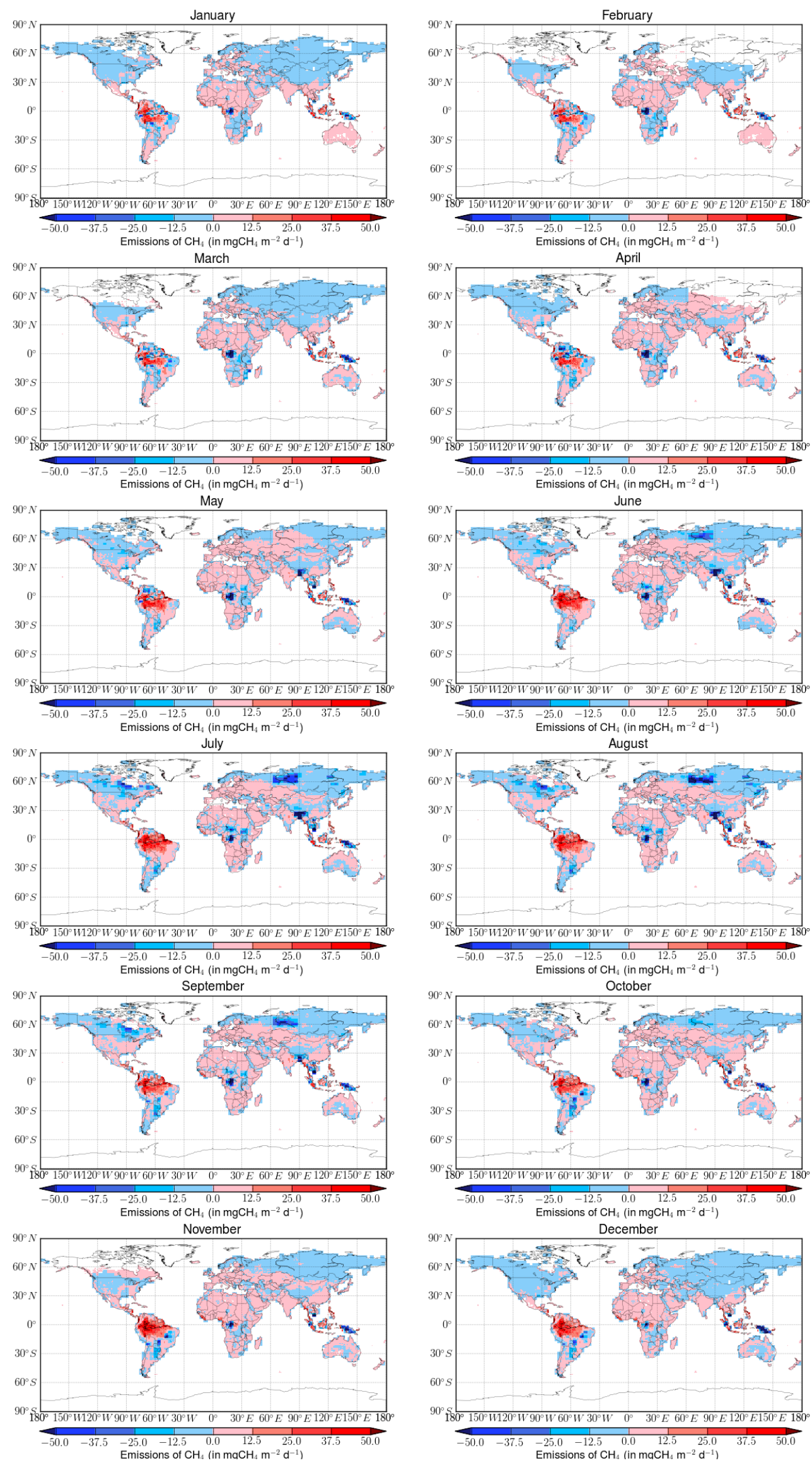

Figure 9: Maps of the differences in the global monthly wetland methane emissions for 2000 between the JULES wetland emission flux and the inverse modelling study of Bousquet et al. (2011) using the Kaplan dataset as the wetland emission prior. 

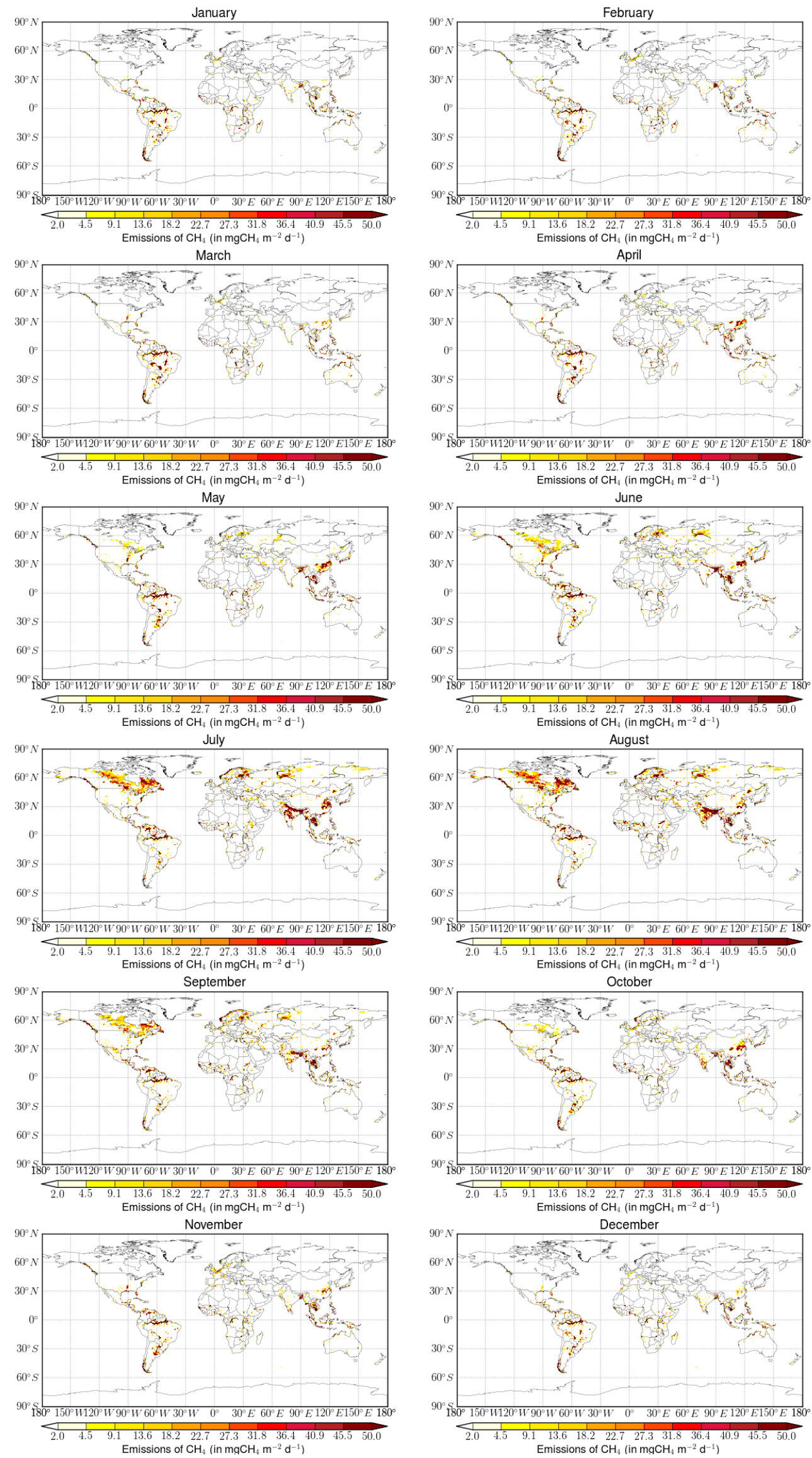

Figure 10: Maps of the global monthly wetland methane emissions for 2000 for the JULES wetland emission flux driven with the GIEMS EO inundation product. 

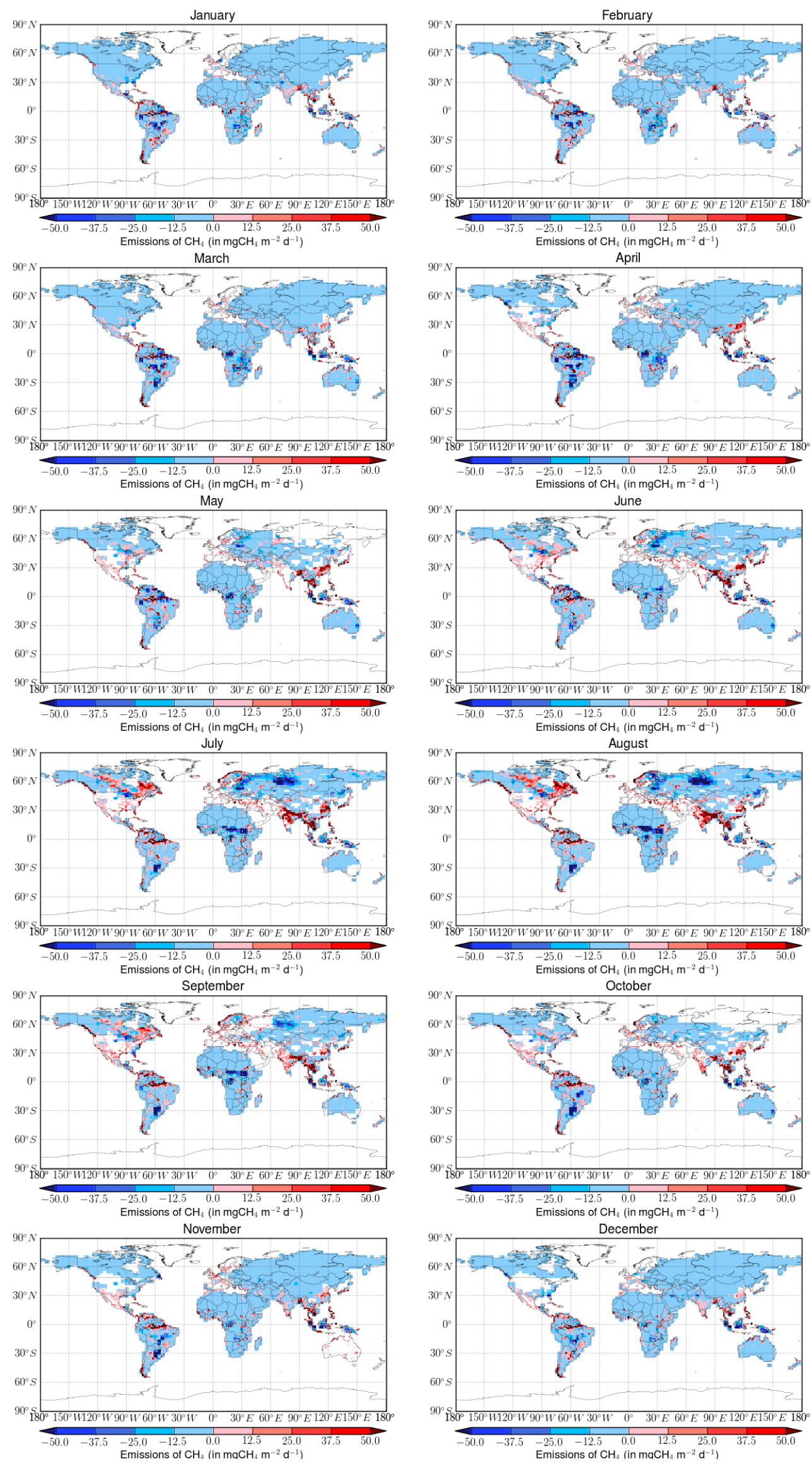

Figure 11: Maps of the differences in the global monthly wetland methane emissions for 2000 between the JULES wetland emission flux driven with the GIEMS product and the inverse modelling study of Bousquet et al. (2011) using the Fung et al. (1991) dataset as the wetland emission prior. 

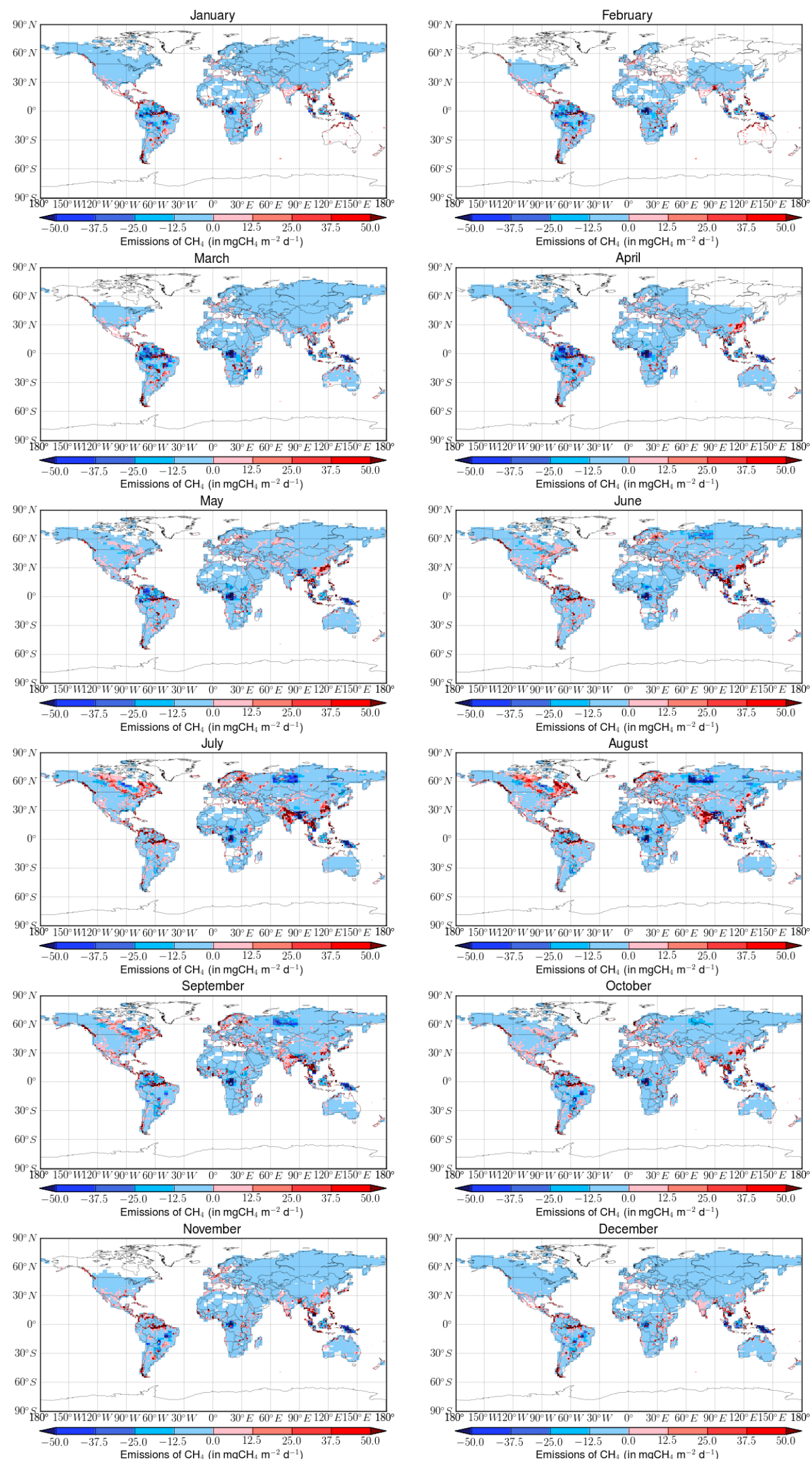

Figure 12: Maps of the differences in the global monthly wetland methane emissions for 2000 between the JULES wetland emission flux driven with the EO inundation product and the inverse modelling study of Bousquet et al. (2011) using the Kaplan dataset as the wetland emission prior. 


\section{Comparison with surface and satellite observations}

\subsection{Surface observations}

The modelled monthly-averaged surface concentrations of atmospheric methane were compared against the monthly-averaged measurements of atmospheric methane dry air mole fractions from the NOAA ESRL GMD Carbon Cycle Cooperative Global Air Sampling Network (Dlugokencky et al., 2012). Fig. 13 shows a map of the locations of the 64 sites used in this work.

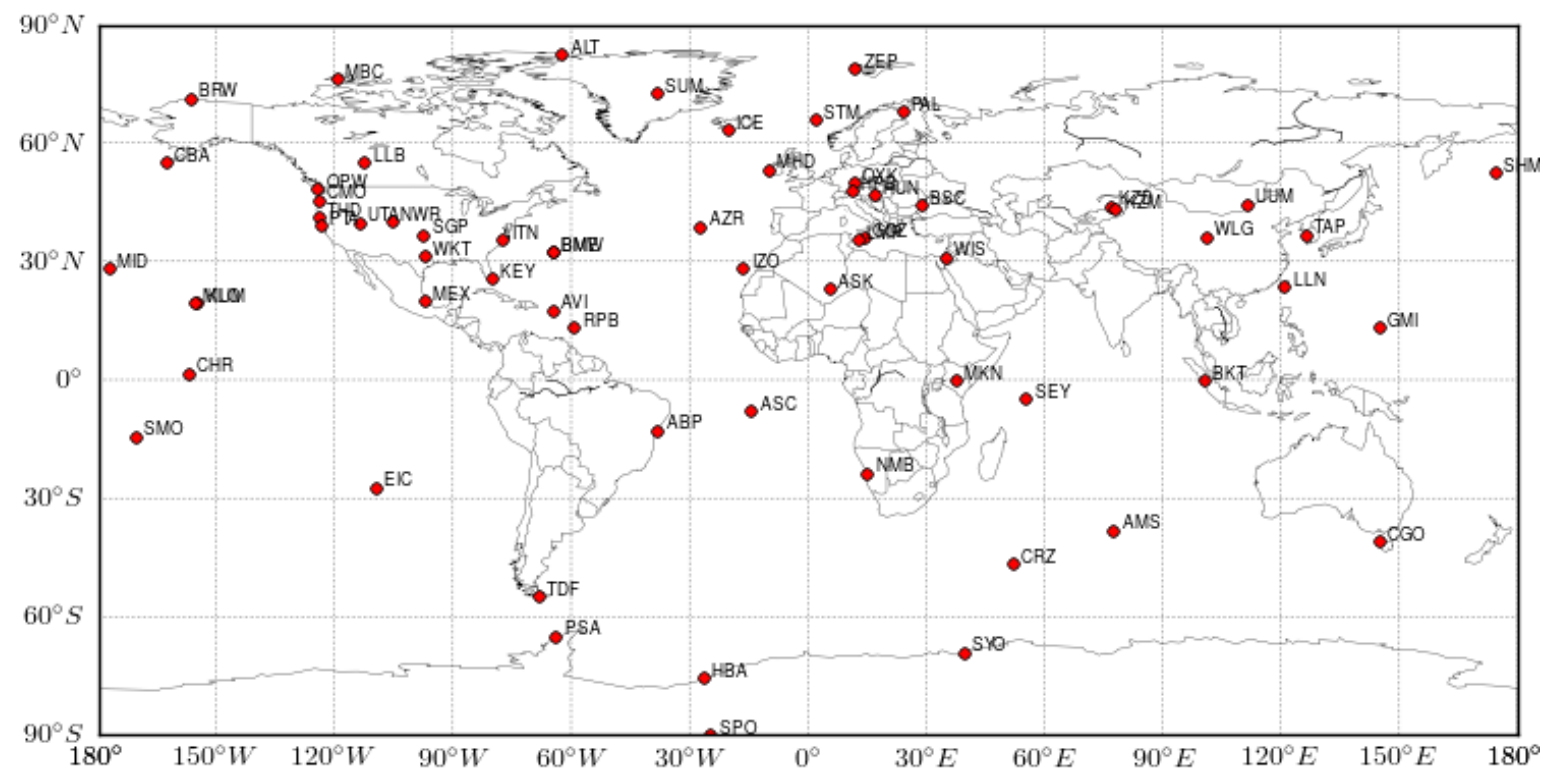

Figure 13: Locations of the surface atmospheric methane sampling sites in the NOAA Global Air Sampling Network: ABP - Arembepe, Bahia; ALT - Alert, Nunavut; AMS - Amsterdam Island; ASC - Ascension Island; ASK - Assekrem; AVI - St. Croix, Virgin Islands; AZR - Terceira Island, Azores; BKT - Bukit Kototabang; BME - St. Davids Head, Bermuda; BMW - Tudor Hill, Bermuda; BRW - Barrow, Alaska; BSC - Black Sea, Constanta; CBA - Cold Bay, Alaska; CGO - Cape Grim, Tasmania; CHR - Christmas Island; CMO - Cape Meares, Oregon; CRZ - Crozet Island; EIC - Easter Island; GMI - Mariana Islands; GOZ - Dwejra Point, Gozo; HBA - Halley Station, Antarctica; HPB Hohenpeissenberg; HUN - Hegyhatsal; ICE - Storhofdi, Vestmannaeyjar; ITN - Grifton, North Carolina; IZO - Tenerife, Canary Islands; KEY - Key Biscayne, Florida; KUM - Cape Kumukahi, Hawaii; KZD - Sary Taukum; KZM - Plateau Assy; LLB - Lac La Biche, Alberta; LLN - Lulin; LMP - Lampedusa; MBC - Mould Bay, Nunavut; MEX - Mex High Altitude Global; MHD - Mace Head, County Galway; MID - Sand Island, Midway; MKN - Mt. Kenya; MLO - Mauna Loa, Hawaii; NMB - Gobabeb; NWR - Niwot Ridge, Colorado; OPW - Olympic Peninsula, Washington; OXK - Ochsenkopf; PAL - PallasSammaltunturi, GAW; PSA - Palmer Station, Antarctica; PTA - Point Arena, California; RPB - Ragged Point; SEY - Mahe Island; SGP - Southern Great Plains, Oklahoma; SHM - Shemya Island, Alaska; SMO - Tutuila; SPO - South Pole, Antarctica; STM - Ocean Station M; SUM - Summit; SYO - Syowa Station, Antarctica; TAP - Tae-ahn Peninsula; TDF - Tierra Del Fuego, Ushuaia; THD - Trinidad Head, California; UTA - Wendover, Utah; UUM - Ulaan Uul; WIS - WIS Station, Negev Desert; WKT - Moody, Texas; WLG - Mt. Waliguan; ZEP - Ny-Alesund, Svalbard.

In Figs. 14-16, we show plots of the observed and modelled atmospheric methane concentrations between 2000 and 2010 at 16 of these sites, covering both northern and southern hemisphere locations, for the different model runs: FUNG, JULES and JULES-GIEMS. We present the metrics derived from the statistical analysis of the observed and modelled concentrations in Tab. 5 . 


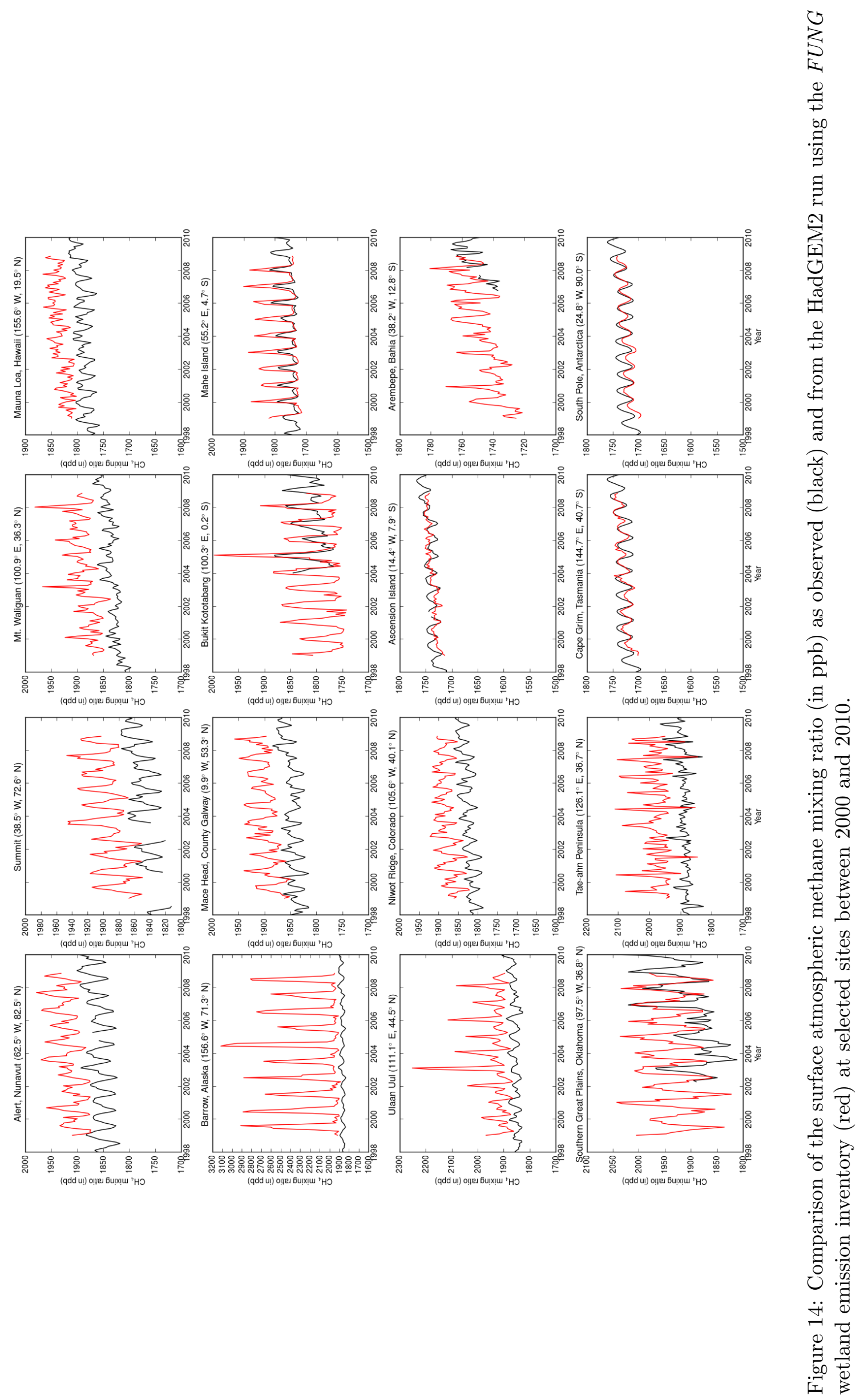




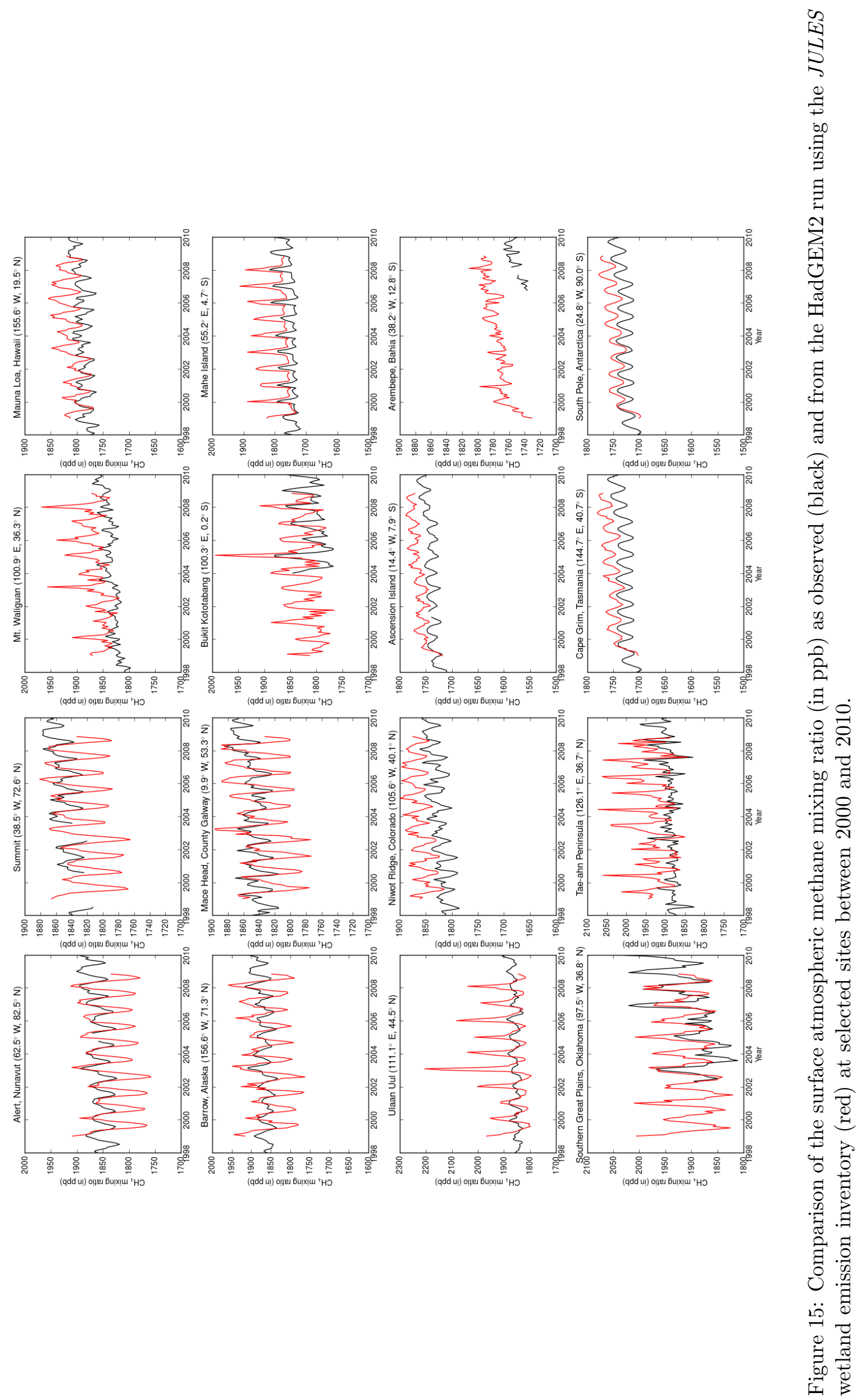



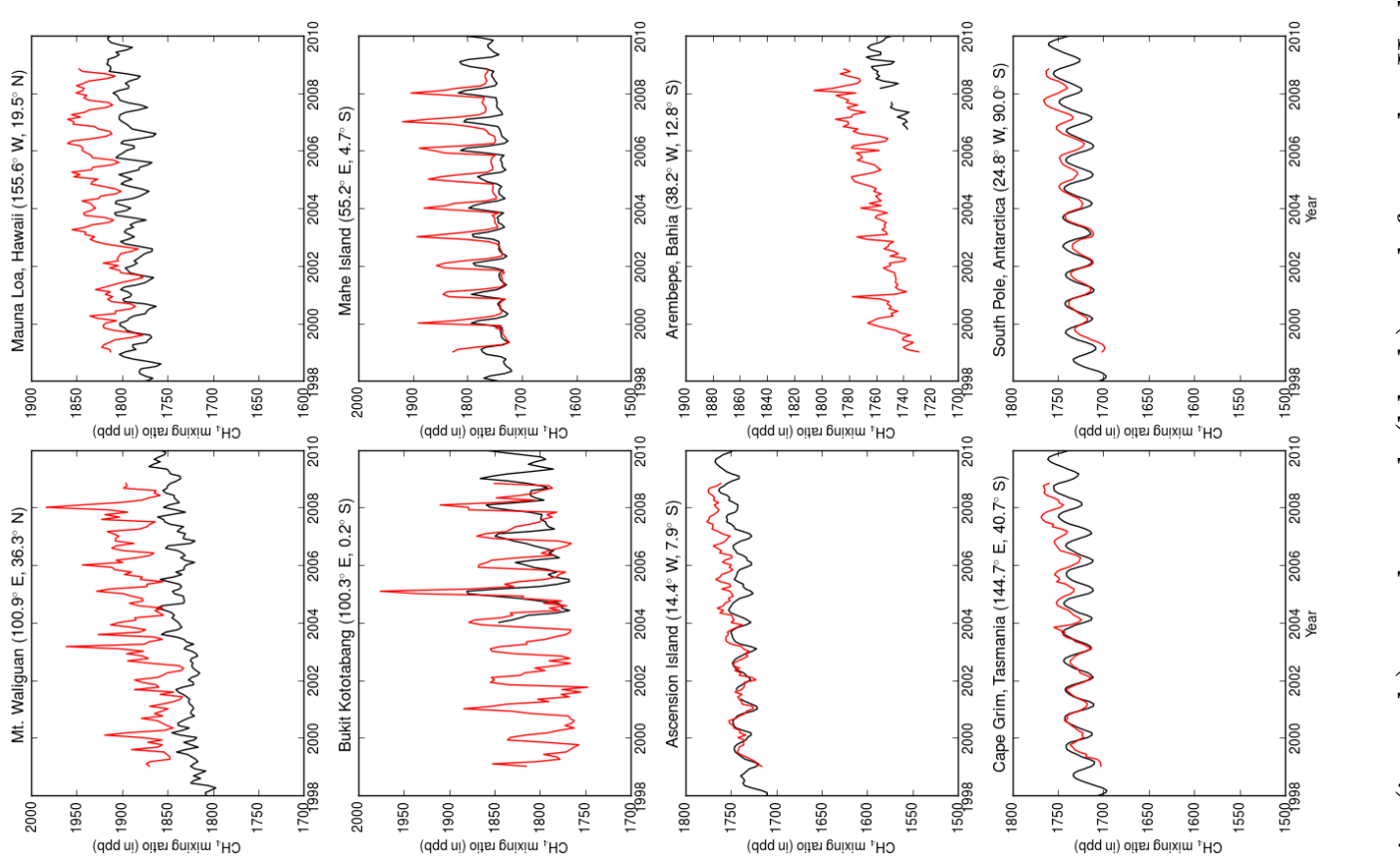

D
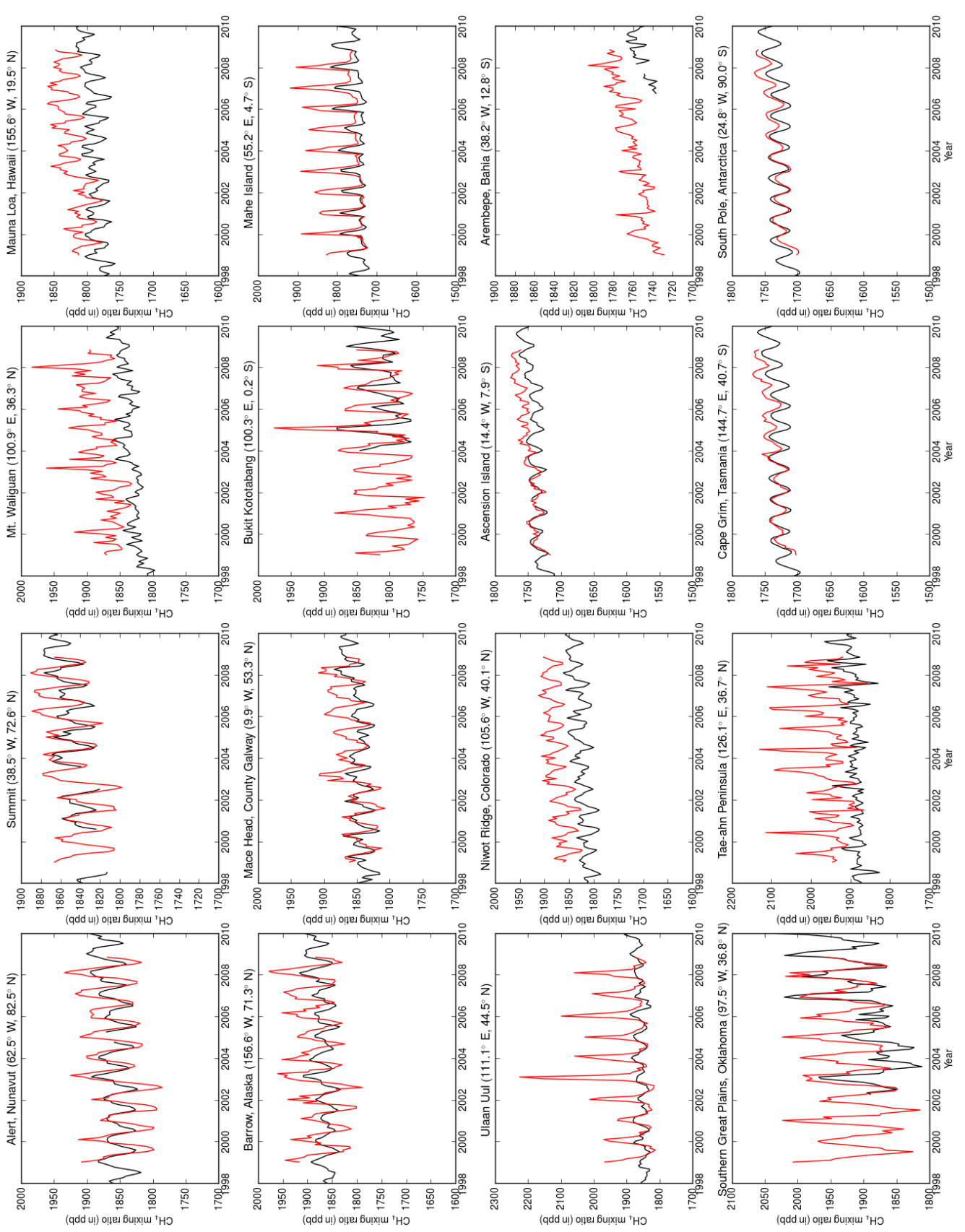

ลิ ส

쿄용 .0 芯 so

离 范 苟 .

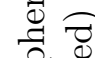
के 䒿 ช 蔦. के $\underset{1}{0}$ 虫 궁 
Table 5: Statistical outputs from the analysis of the observed and modelled surface methane concentrations at Barrow and the South Pole for the the three HadGEM2 runs (FUNG, JULES and JULES-GIEMS).

(a) Barrow

\begin{tabular}{l|c|c|c}
\hline Statistic/Metric & FUNG & JULES & $\begin{array}{c}\text { JULES- } \\
\text { GIEMS }\end{array}$ \\
\hline Number of valid data pairs & & & 119 \\
Linear regression - slope & -12.15 & 119 & 1.68 \\
Linear regression - intercept & 24840.99 & -1308.71 & -1262.04 \\
Coefficient of determination ( $\left.{ }^{2}\right)$ & 0.46 & 0.39 & 0.49 \\
Mean of Observations (in ppb) & 1867.79 & 1867.79 & 1867.79 \\
Mean of Modelled Conc. (in ppb) & 2147.09 & 1861.35 & 1882.11 \\
Mean normalised bias & 0.15 & -0.004 & 0.008 \\
Number of modelled results within a fac- & 1.00 & 1.00 & 1.00 \\
tor of 2 of that observed & & & \\
Index of Agreement & 0.01 & 0.60 & 0.64 \\
Hit Rate & 0.55 & 1.00 & 1.00 \\
Root Mean Square Error (RMSE in ppb) & 425.82 & 39.19 & 34.82 \\
Coefficient of Variation in RMSE & 0.29 & 0.02 & 0.02 \\
\hline
\end{tabular}

(b) South Pole

\begin{tabular}{l|c|c|c}
\hline Statistic/Metric & FUNG & JULES & $\begin{array}{c}\text { JULES- } \\
\text { GIEMS }\end{array}$ \\
\hline Number of valid data pairs & 119 & 119 & 119 \\
Linear regression - slope & 0.72 & 1.07 & 0.96 \\
Linear regression - intercept & 471.70 & -97.51 & 79.48 \\
Coefficient of determination (R $\left.{ }^{2}\right)$ & 0.60 & 0.62 & 0.59 \\
Mean of Observations (in ppb) & 1729.16 & 1729.16 & 1729.16 \\
Mean of Modelled Conc. (in ppb) & 1723.82 & 1746.40 & 1733.13 \\
Mean normalised bias & -0.003 & 0.01 & 0.002 \\
Number of modelled results within a fac- & 1.00 & 1.00 & 1.00 \\
tor of 2 of that observed & & & \\
Index of Agreement & 0.84 & 0.66 & 0.85 \\
Hit Rate & 1.00 & 1.00 & 1.00 \\
Root Mean Square Error (RMSE in ppb) & 9.49 & 19.96 & 10.44 \\
Coefficient of Variation in RMSE & 0.005 & 0.012 & 0.006 \\
\hline
\end{tabular}




\subsection{Satellite observations}

The modelled 4-D methane mass mixing ratio fields (longitude, latitude, altitude, time) were converted into 3-D fields (longitude, latitude, time) of the mean atmospheric column methane mixing ratio, using the SCIAMACHY averaging kernels (equation 4 in Schneising et al., 2009).

$$
\mathrm{XCH}_{4}^{\text {model }}=\frac{1}{\mathrm{p}_{0}} \sum_{l}\left[\overline{\mathrm{XCH}}_{4}^{l}+\mathrm{AK}^{l}\left(\mathrm{XCH}_{4}^{\text {model } l}-\overline{\mathrm{XCH}}_{4}^{l}\right)\right] \Delta \mathrm{p}^{l}
$$

where $l$ is the index of the vertical layer, $\mathrm{AK}^{l}$ the averaging kernel, $\overline{\mathrm{XCH}}_{4}^{l}$ the a-priori mole fraction (1750 ppb below 6km and decreasing above) and $\mathrm{XCH}_{4}$ model $l$ is the modelled mole fraction of layer $l . \Delta \mathrm{p}^{l}$ is the pressure difference between the upper and lower boundary of layer $l$ and $\mathrm{p}_{0}$ denotes the surface pressure.

As discussed in the main paper, the modelled atmospheric methane columns underpredicted the columns in the Sciamachy dataset. To overcome this limitation, the methane concentration in the upper model layers were replaced initially using data from the thermal infrared channel of the Tropospheric Emission Spectrometer and subsequently with output from a TOMCAT model run, assimilated with ACE and HALOE data. Fig. 17 presents contour maps of the annual mean atmospheric column measurements of methane as derived from the unconstrained (panel a) and constrained HadGEM2 (panel b) run and from the monthly regridded Sciamachy data (v2.3, panel c). The Sciamachy and model atmospheric methane columns have been sampled at common, valid space and time points. A land mask was applied to remove all data over the ocean as the Sciamachy data are only available over the oceans for the period between 2003 and 2005. 
(a)

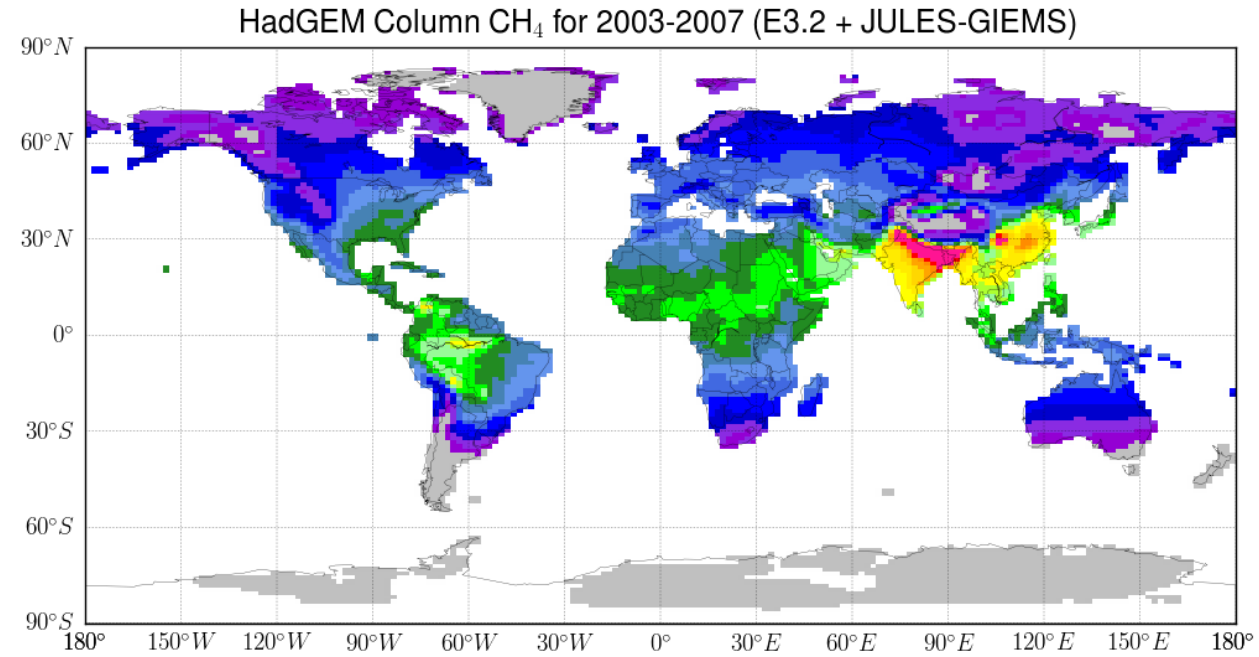

(b)

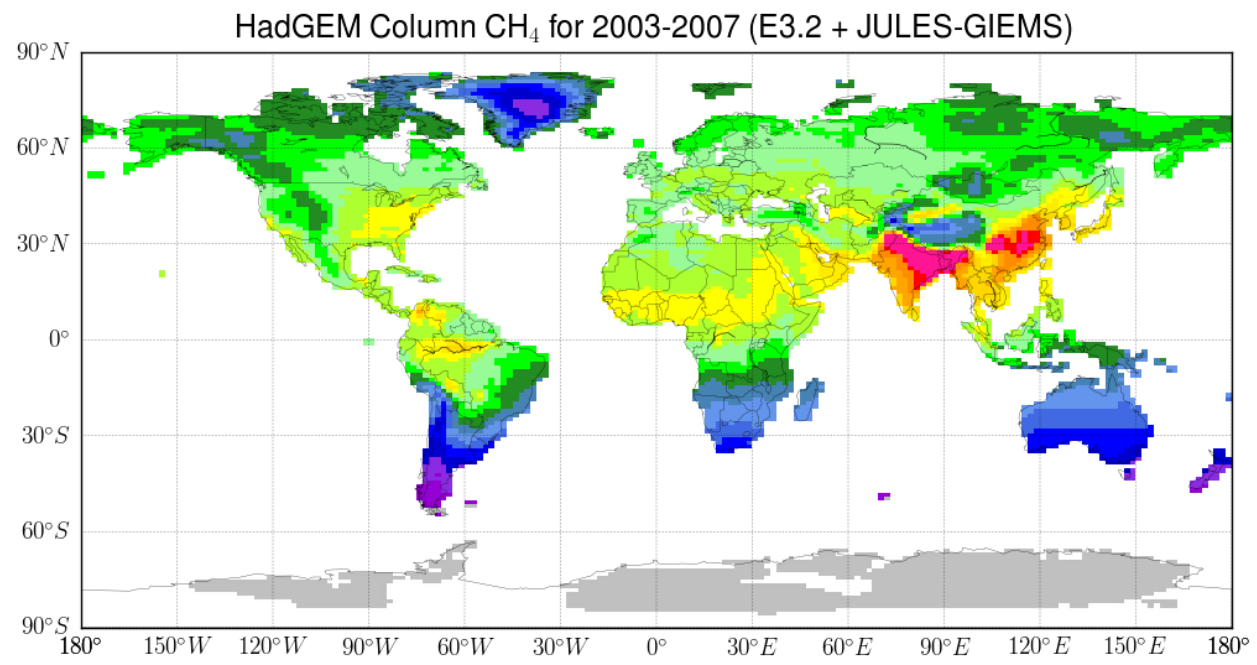

(c)

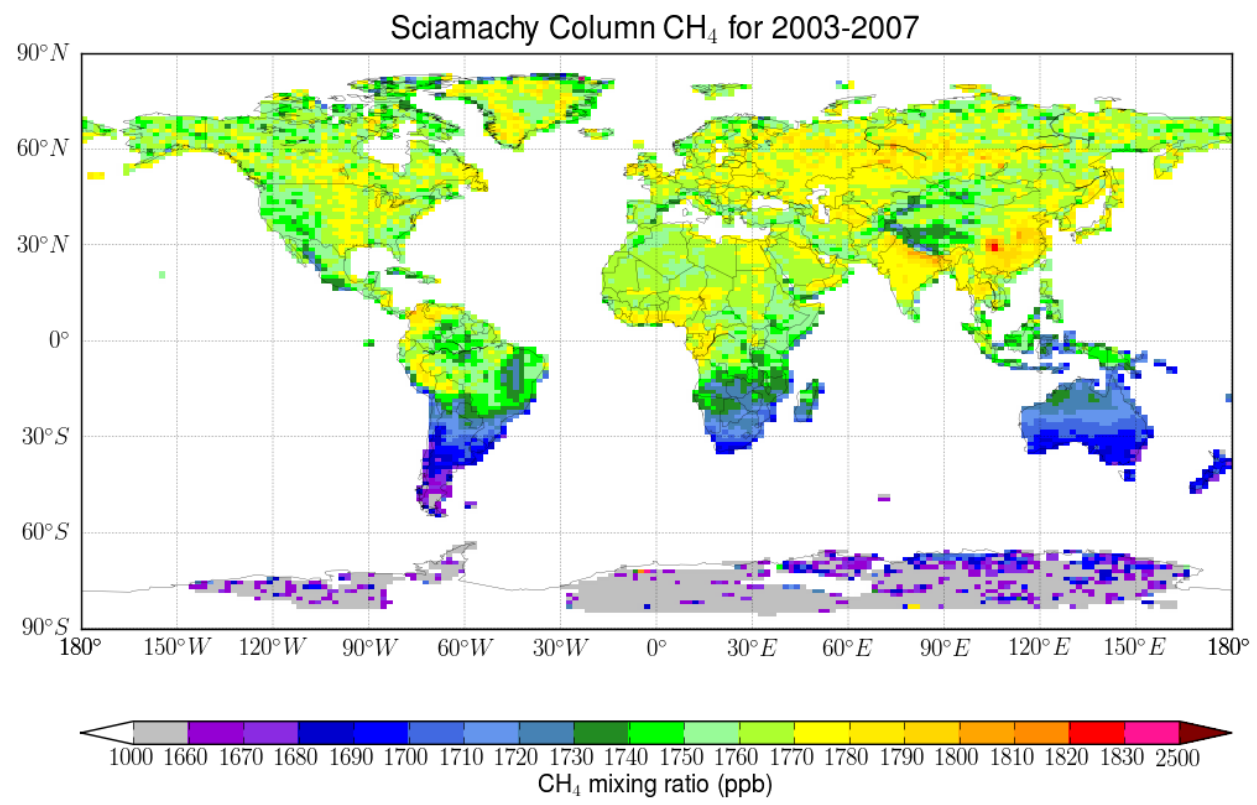

Figure 17: Contour maps of the average atmospheric column methane mixing ratio for 20032007 as derived from the unconstrained (panel a) and constrained HadGEM2 (panel b) run and from monthly regridded Sciamachy data (v2.3, panel c), sampled at common space and time points. 


\section{References}

Best, M. J., Pryor, M., Clark, D. B., Rooney, G. G., Essery, R. L. H., Ménard, C. B., Edwards, J. M., Hendry, M. A., Porson, A., Gedney, N., Mercado, L. M., Sitch, S., Blyth, E., Boucher, O., Cox, P. M., Grimmond, C. S. B., and Harding, R. J.: The Joint UK Land Environment Simulator (JULES), model description - Part 1: Energy and water fluxes, Geoscientific Model Development, 4, 677-699, doi:10.5194/gmd-4-677-2011, http://www.geosci-model-dev.net/4/677/2011/, 2011.

Bousquet, P., Ringeval, B., Pison, I., Dlugokencky, E. J., Brunke, E.-G., Carouge, C., Chevallier, F., Fortems-Cheiney, A., Frankenberg, C., Hauglustaine, D. A., Krummel, P. B., Langenfelds, R. L., Ramonet, M., Schmidt, M., Steele, L. P., Szopa, S., Yver, C., Viovy, N., and Ciais, P.: Source attribution of the changes in atmospheric methane for 2006-2008, Atmospheric Chemistry and Physics, 11, 3689-3700, doi:10.5194/acp-11-3689-2011, http://www .atmos-chem-phys.net/11/3689/2011/, 2011.

Clark, D. B., Mercado, L. M., Sitch, S., Jones, C. D., Gedney, N., Best, M. J., Pryor, M., Rooney, G. G., Essery, R. L. H., Blyth, E., Boucher, O., Harding, R. J., Huntingford, C., and Cox, P. M.: The Joint UK Land Environment Simulator (JULES), model description - Part 2: Carbon fluxes and vegetation dynamics, Geoscientific Model Development, 4, 701-722, doi:10.5194/gmd-4-701-2011, http://www.geosci-model-dev.net/4/701/2011/, 2011.

Collins, W. J., Bellouin, N., Doutriaux-Boucher, M., Gedney, N., Halloran, P., Hinton, T., Hughes, J., Jones, C. D., Joshi, M., Liddicoat, S., Martin, G., O’Connor, F., Rae, J., Senior, C., Sitch, S., Totterdell, I., Wiltshire, A., and Woodward, S.: Development and evaluation of an Earth-System model - HadGEM2, Geoscientific Model Development, 4, 1051-1075, doi:10.5194/gmd-4-1051-2011, http://www.geosci-model-dev.net/4/1051/2011/, 2011.

Dlugokencky, E. J., Lang, P. M., Crotwell, A. M., and Masarie, K. A.: Atmospheric Methane Dry Air Mole Fractions from the NOAA ESRL Carbon Cycle Co-operative Global Air Sampling Network, 1983-2011, Version: 2012-09-24, ftp://ftp.cmdl.noaa.gov/ccg/ch4/flask/event/, 2012.

Fung, I., John, J., Lerner, J., Matthews, E., Prather, M., Steele, L. P., and Fraser, P. J.: Threedimensional model synthesis of the global methane cycle, Journal of Geophysical Research: Atmospheres, 96, 13 033-13 065, doi:10.1029/91JD01247, http://dx.doi .org/10.1029/91JD01247, 1991.

Gedney, N.: Unpublished results from JULES, 2014.

Gedney, N. and Cox, P. M.: The Sensitivity of Global Climate Model Simulations to the Representation of Soil Moisture Heterogeneity, Journal of Hydrometeorology, 4, 1265-1275, doi:10.1175/1525-7541(2003)004¡1265:TSOGCM;2.0.CO;2, http://dx .doi .org/10.1175/1525-7541 (2003)004<1265: TSOGCM>2 . 0. C0;2, 2003.

Gedney, N., Cox, P. M., and Huntingford, C.: Climate feedback from wetland methane emissions, Geophysical Research Letters, 31, L20 503, doi:10.1029/2004GL020919, http://dx.doi.org/10.1029/2004GL020919, 2004.

Lamarque, J.-F., Bond, T. C., Eyring, V., Granier, C., Heil, A., Klimont, Z., Lee, D., Liousse, C., Mieville, A., Owen, B., Schultz, M. G., Shindell, D., Smith, S. J., Stehfest, E., Van Aardenne, J., Cooper, O. R., Kainuma, M., Mahowald, N., McConnell, J. R., Naik, V., Riahi, K., and van Vuuren, D. P.: Historical (1850-2000) gridded anthropogenic and biomass burning emissions of reactive gases and aerosols: methodology and application, Atmospheric Chemistry and Physics, 10, 7017-7039, doi: 10.5194/acp-10-7017-2010, http://www . atmos-chem-phys.net/10/7017/2010/, 2010.

O'Connor, F. M., Johnson, C. E., Morgenstern, O., Abraham, N. L., Braesicke, P., Dalvi, M., Folberth, G. A., Sanderson, M. G., Telford, P. J., Young, P. J., Zeng, G., Collins, W. J., and Pyle, J. A.: Evaluation of the new UKCA climate-composition model - Part 2: The Troposphere, Geoscientific Model Development Discussions, 6, 1743-1857, doi:10.5194/gmdd-6-1743-2013, http://www.geosci-model-dev-discuss.net/6/1743/2013/, 2013.

Portmann, F. T., Siebert, S., and Döll, P.: MIRCA2000 - Global monthly irrigated and rainfed crop areas around the year 2000: A new high-resolution data set for agricultural and hydrological modeling, Global Biogeochemical Cycles, 24, GB1001, doi:10.1029/2008GB003435, http://dx.doi.org/10.1029/2008GB003435, 2010.

Prigent, C., Papa, F., Aires, F., Jimenez, C., Rossow, W. B., and Matthews, E.: Changes in land surface water dynamics since the 1990s and relation to population pressure, Geophysical Research Letters, 39, L08 403, doi:10.1029/2012GL051276, http://dx.doi .org/10.1029/2012GL051276, 2012.

Schneising, O., Buchwitz, M., Burrows, J. P., Bovensmann, H., Bergamaschi, P., and Peters, W.: Three years of greenhouse gas column-averaged dry air mole fractions retrieved from satellite Part 2: Methane, Atmospheric Chemistry and Physics, 9, 443-465, doi:10.5194/acp-9-443-2009, 
http://www . atmos-chem-phys .net/9/443/2009/, 2009.

van der Werf, G. R., Randerson, J. T., Giglio, L., Collatz, G. J., Mu, M., Kasibhatla, P. S., Morton, D. C., DeFries, R. S., Jin, Y., and van Leeuwen, T. T.: Global fire emissions and the contribution of deforestation, savanna, forest, agricultural, and peat fires (1997-2009), Atmospheric Chemistry and Physics, 10, 11 707-11 735, doi:10.5194/acp-10-11707-2010, http://www . atmos-chem-phys .net/10/11707/2010/, 2010.

Viovy, N. and Ciais, P.: A combined dataset for ecosystem modelling, available at: http://dods.extra.cea.fr/data/p529viov/cruncep/readme.htm (last access: 10 July 2013), 2009. 